\title{
Is the China-effect real? Ideational change and the political contestation of Chinese state-led investment in Europe
}

\author{
Milan Babić ${ }^{1}$, Adam D. Dixon ${ }^{2}$ \\ ${ }^{1}$ Department of Social Sciences and Business, Roskilde University \\ 2 Faculty of Arts and Social Sciences, Maastricht University
}

\section{Forthcoming in the Chinese Journal of International Politics}

\begin{abstract}
Chinese outwards investment is increasing in its relevance for the global economy; and its effects on host states are increasingly being scrutinized globally. While European policymaking was ambiguous about the question of hosting Chinese state-led investment in the early 2010s, we can observe a recent surge of protectionist legal measures across Europe. What explains this trend among different European countries? Through the lens of incremental ideational change, we hypothesize that the rise of China as a global investor shifts the perceptions of policy-makers away from being a source of investment towards a potential threat to national security. We argue that this China-effect affects advanced European economies similarly. We provide evidence by studying the shift in perceptions among policy-makers in a coordinated and a liberal market economy, Germany and the UK. By drawing on document analysis and expert interviews, we unpack the policy processes in both countries in the last decade. Despite being two dissimilar cases, both show a similar outcome in increasingly curbing Chinese state-led investment on the grounds of national security reasons. Our results add important insights to recent International Political Economy discussions on the "geopoliticization" of European trade and investment rules in the face of a rising China.
\end{abstract}

Wordcount: 14.942 (incl. notes, references, tables and figures; without abstract)

\section{Contact:}

Email: babic@ruc.dk

Twitter: @mbabic_1

Homepage: milanbabic.com 


\section{Acknowledgments}

We are grateful to Sarah Bauerle Danzman, Jan Fichtner, Lukas Linsi, Imogen Liu and Mark Herman Schwartz for valuable feedback on previous versions of this paper. We also thank our interviewees for making space for us in their busy schedules, the CJIP editor and two anonymous reviewers for constructive comments, as well as the participants of the ISA and MPSA conferences 2021 and the CHERN WG1-WG3 paper development workshop, where this paper has been presented. This work was supported by the European Research Council (ERC) under the European Union's Horizon 2020 research and innovation programme (grant agreement no. 758430). 


\section{Introduction}

Over the last two decades, Chinese state-led investment (CSLI) has moved from being a relatively new phenomenon in the global economy to the center of disputes about foreign investment screening mechanisms, rising protectionism, and renewed global rivalries. When China entered the World Trade Organization (WTO) in 2001, many Western policy-makers attached high hopes to the opening of a growing consumer market, fostering China's integration in the liberal economic order and supporting domestic political change. However, while the global public's attention was on trade, important changes in foreign direct investment (FDI) were taking hold. During the 1990s China experienced a boom of inward investment. In the early 2000s, China's outward investment started growing and expanded significantly after the 2008 Global Financial Crisis (GFC). ${ }^{1}$ Some countries, such as the UK, even actively embraced this investment windfall in the difficult economic post-crisis years. Yet, while many observers welcomed the integration of Chinese capital into the global economy, skepticism towards Chinese state-led investment also began to grow. ${ }^{2}$ Today, the uneasiness surrounding Chinese investment has already produced tangible political consequences, such the introduction of comprehensive investment screening mechanisms at European and national levels. ${ }^{3}$

What explains this shift over the last decade? In this paper, we hypothesize that the rise of China as an investor in the global political economy initiated a gradual ideational change among policy-makers in Europe regarding the benefits and drawbacks of inward foreign investment in general, and CSLI in particular. What at the beginning of the 2010s was perceived as a welcome source of capital, was at the end of the decade perceived as a threat to national and economic security in strategically important sectors in many high-income economies. Policymakers in Europe increasingly deem the drawbacks of a "sellout" of critical infrastructures, strategic assets and sensitive technologies to China to be higher than the

\footnotetext{
${ }^{1}$ David Shambaugh, China Goes Global. The Partial Power (Oxford: Oxford University Press, 2013), p. 138.

${ }^{2}$ Philippe Le Corre, "Chinese Investments in European Countries: Experiences and Lessons for the 'Belt and Road' Initiative," in Maximilian Mayer, ed., Rethinking the Silk Road (Singapore: Springer, 2018), pp. 161-75; Sophie Meunier, "Chinese Direct Investment in Europe: Economic Opportunities and Political Challenges," in Ka Zeng, ed., Handbook on the International Political Economy of China (Cheltenham: Edward Elgar Publishing, 2019), pp. 98-112.

3 Philipp Stompfe, "Foreign Investment Screening in Germany and France," in Steffen Hindelang and Andreas Moberg, eds., YSEC Yearbook of Socio-Economic Constitutions (Cham: Springer International Publishing, 2020).
} 
benefits of CSLI in these sectors. This, we argue, has palpable consequences for the role of Europe as a global investment destination. Instead of creating a global level playing field for trade and investment, the EU and many of its member states increasingly engage in what has been aptly described as the "geopoliticization" of trade and investment policies. ${ }^{4}$ New and comprehensive protectionist policies are gaining ground and are a symptom of this broader trend of a "securitisation" of Chinese economic presence in the EU. ${ }^{5}$

We substantiate this argument by comparing what are two dissimilar cases in comparative capitalism research ${ }^{6}$, namely the UK (a liberal market economy - LME) and Germany (a coordinated market economy - CME). By drawing on newspaper articles, policy documents, think tank reports, and expert interviews in both countries, we reconstruct how both policy-making communities shifted from a relatively open policy vis-à-vis CSLI after the GFC towards an ever stronger curbing of such investment forms. If the rise of China as a global investor is a systemic independent variable, its effect on different capitalist varieties should be similar. This does not mean that the rise of CSLI will flatten out different capitalist varieties. Rather, we hypothesize that the pressures exerted by the rise of China will move different capitalist varieties in the same direction, but from different starting points. Open economies like the UK will still have a less protectionist stance towards CSLI than economies like Germany. Yet, open economies will be more protectionist today compared to a decade ago. We call this convergence pressure leading to similar, but uneven outcomes in the economic policies of European states the China-effect.

Theoretically, we draw on the literature on incremental ideational change to capture how the rise of CSLI in strategic sectors and the concomitant ideational changes did not happen in a "big bang"-like manner, but have been unfolding roughly over the last 10 years. ${ }^{7}$ The China-

\footnotetext{
" Sophie Meunier and Kalypso Nicolaidis, "The Geopoliticization of European Trade and Investment Policy," JCMS: Journal of Common Market Studies, Vol. 57, No. 1 (2019), pp. 103-113.

${ }^{5}$ Igor Rogelja and Konstantinos Tsimonis, "Narrating the China Threat: Securitising Chinese Economic Presence in Europe," The Chinese Journal of International Politics Vol. 13, No. 1 (2020), pp. 103-133.

${ }^{6}$ Peter A. Hall and David Soskice, "An Introduction to Varieties of Capitalism," in Peter A. Hall and David Soskice, eds., Varieties of Capitalism: The Institutional Foundations of Comparative Advantage (Oxford: Oxford University Press, 2001), pp. 1-68.

${ }^{7}$ Martin B. Carstensen, "Ideas Are Not as Stable as Political Scientists Want Them to Be: A Theory of Incremental Ideational Change," Political Studies Vol. 59, No. 3 (2011), pp. 596-615; Manuela Moschella, "The Institutional Roots of Incremental Ideational Change: The IMF and Capital Controls after the Global Financial Crisis," The British Journal of Politics and International Relations Vol. 17, No. 3 (2015), pp. 442-460.
} 
effect is in this reading different from a China-shock. This approach helps to better understand how new ideas emerge from existing ideational and institutional ensembles and thereby also contain contradictory or diffuse elements. An events-driven analysis of ideational change often attributes too much significance to singular events and thereby implicitly assumes a clear delineation between different (economic) policy paradigms governing politics. ${ }^{8}$ While this may be true for what Hall calls paradigmatic "third order change" ${ }^{\prime \prime}$, our case is a typical example of a slow, incremental, and contradictory adaptation of policy-makers to changing global realities. We thus stress the "bricolage"-character of the incremental ideational shift described herein, "where bits and pieces of the existing ideational and institutional legacy are put together in new forms leading to significant political transformation". ${ }^{10}$ The rise of CSLI, especially in sensitive sectors, and its effects on policy-making in Europe are a case in point as we show below.

Our contribution is threefold: first, we hypothesize and operationalize the China-effect and outline its main working mechanisms for further empirical testing. We delineate a research agenda based on this inductive work that allows future research to test different aspects and variations of the hypothesized effect. Second, we add new comparative evidence for the Chinaeffect, tracing how policy-making of European states vis-à-vis CSLI changes over time, and how these changes are not driven by changing political constellations but rather represent a stable trend. To our knowledge, this is the first time that these cross-temporal political dynamics are studied comprehensively. By studying two dissimilar cases, we add leverage to the argument that country-specific factors explain the degree, but not the general direction of the Chinaeffect. Third, we contribute to current discussions on the role of Europe in a changing global order, and how the rise of China affects these changes to a significant degree. ${ }^{11}$ Our findings help to better estimate how European economic policy-making vis-à-vis China will develop in the coming years.

\footnotetext{
${ }^{8}$ Mark Blyth, Great Transformations: Economic Ideas and Institutional Change in the Twentieth Century (Cambridge: Cambridge University Press, 2002); Peter A. Hall, "Policy Paradigms, Social Learning, and the State: The Case of Economic Policymaking in Britain," Comparative Politics Vol. 25, No. 3 (1993), pp. 275-96. ${ }^{9}$ Hall, "Policy Paradigms, Social Learning, and the State," p. 283.

${ }^{10}$ Martin B. Carstensen, "Paradigm Man vs. the Bricoleur: Bricolage as an Alternative Vision of Agency in Ideational Change," European Political Science Review Vol. 3, No. 1 (2011), pp. 147-67, here: p. 147. ${ }^{11}$ See Scott Lavery and Davide Schmid, "European Integration and the New Global Disorder," JCMS: Journal of Common Market Studies Vol. 59, No. 5 (2021), pp. 1322-38.
} 
We proceed by describing the role and forms of CSLI within Europe in recent years (next section). We then provide a theoretical framework for analyzing the effects of CSLI for incremental ideational change among policy-makers (section "The China-effect"). In the section that follows ("From embracing to protectionism"), we compare our two cases, tracing the described ideational shifts through the last decade. In the discussion section, we scrutinize our findings against possible objections regarding our conceptualization and interpretation of the empirical results. We close by outlining a comprehensive future research agenda based on the findings of our paper (section "Conclusion").

\section{The Rise of Chinese State-Led Investment in a Globalized Economy}

\section{From "Opening Up" to "Going Global"}

China's rise as global trading and investment power in the last three decades is closely tied to structural advantages of the Chinese economy in combination with a cautious but strategic long-term approach of integrating China into the global economy. ${ }^{12}$ State power and control has played a crucial role in this integration process. From 1978, Deng Xiaoping's government undertook major reforms that were summarized as "opening up" China for the first time to the global economy. Different from other transition economies in East Asia or the Soviet Union, China retained a large degree of state control over its developmental trajectory. This was also the case for the state ownership reforms during the 1990s. ${ }^{13}$ Whereas in cases like Russia we saw the large-scale privatization of state-owned assets, China opted for fundamental but controlled reforms. ${ }^{14}$ This also involved nominally giving up state ownership in order to modernize the old, and often inefficient state conglomerates under ministerial supervision. This nominal reduction was in fact a re-concentration of economic state power. Although, for example, the absolute number and the total employment of state-owned enterprises were

\footnotetext{
12 Shaun Breslin, China and the Global Political Economy (London: Palgrave Macmillan, 2013).

${ }^{13}$ Xi Chen, "Elitism and Exclusion in Mass Protest: Privatization, Resistance, and State Domination in China," Comparative Political Studies Vol. 50, No. 7 (2017), pp. 908-34.

${ }^{14}$ Isabella Weber, How China Escaped Shock Therapy: The Market Reform Debate (New York: Routledge, 2021).
} 
significantly reduced ${ }^{15}$, the assets under management as well as the net income of those SOEs soared dramatically. ${ }^{16}$

These and further transformation processes laid the foundation for China's "going out" policy formulated in the late 1990s. To achieve different macroeconomic and developmental goals, the Chinese government promoted outwards FDI to similar degrees as it tried to attract inward investment. SOEs and other state-led investment forms played a crucial role in this project and were transformed to increase their competitiveness and ability to integrate into foreign markets. A milestone of this transformation was the creation of the State-owned Assets Supervision and Administration Commission (SASAC) in 2003. Initially managing around 200 firms, further mergers and reforms reduced the number of SASAC companies to under 100 today. The strong performance and growth (both in economic terms as well as its workforce) shows how SASAC fosters a state-ownership sector in China that is dominated by large, powerful national champions. ${ }^{17}$ This is also the basis for large-scale, state-led foreign investment by China. Landmark deals such as the takeovers of Dutch Nidera in 2014, of German KraussMaffei in 2016, or of Swiss Syngenta in 2017 were all conducted by SASAC firms. Beyond SASAC, a tight network of ministries and state agencies coordinates both the broad policy lines (like the State Council or the Ministry of Finance) as well as the practical implementation (like the Ministry of Commerce or the National Development and Reform Commission) of outwards (state-led and "private") investment. ${ }^{18}$ Today, this strategic aspect of retaining (state) control is widely recognizable across different aspects of Chinese domestic and cross-border liberalization, such as trade, investment, or finance. ${ }^{19}$

\footnotetext{
${ }^{15}$ Barry Naughton, "The Transformation of the State Sector: SASAC, the Market Economy, and the New National Champions," in Barry Naughton and Kellee S. Tsai, eds., State Capitalism, Institutional Adaptation, and the Chinese Miracle (Cambridge: Cambridge University Press, 2015), pp. 46-72.

${ }^{16}$ Karen Jingrong Lin, Xiaoyan Lu, Junsheng Zhang, and Ying Zheng, "State-Owned Enterprises in China: A Review of 40 Years of Research and Practice," China Journal of Accounting Research Vol. 13, No. 1 (2020), pp. 31-55, here: p. 33.

${ }^{17}$ Naughton, The Transformation of the State Sector.

${ }^{18}$ Huang Wenbin and Andreas Wilkes, "Analysis of China's Overseas Investment Policies," CIFOR Working Paper, No. 79 (2011).

${ }^{19}$ Roselyn Hsueh, "China and India in the Age of Globalization: Sectoral Variation in Postliberalization Reregulation," Comparative Political Studies Vol. 45, No. 1 (2012), pp. 32-61; Steven Liao and Daniel McDowell, "Redback Rising: China's Bilateral Swap Agreements and Renminbi Internationalization," International Studies Quarterly Vol. 59, No. 3 (2015), pp. 401-22; but see also Kristen Hopewell, "Strategic Narratives in Global Trade Politics: American Hegemony, Free Trade, and the Hidden Hand of the State," The Chinese Journal of International Politics Vol. 14, No. 1 (2021), pp. 51-86; David A. Lake, "Economic Openness and Great Power Competition: Lessons for China and the United States," The Chinese Journal of International Politics Vol. 11, No. 3 (2018), pp. 237-70.
} 


\section{Europe as investment target}

Europe plays a major role today for the Chinese efforts of going out and going global. Besides being a large, high-income consumer market, Europe is also home to some of the world's leading industrial and high-tech firms with important tacit knowledge and assets relevant for Chinese upscaling. These sensitive or strategic sectors are particularly relevant for the Chinaeffect as we describe it in this paper. In addition, the EU single market was for a long time relatively open for foreign investment in accordance with its "global level playing field" approach to international trade and investment. ${ }^{20}$ This means that when Chinese foreign investment took off in the 2000s, it was not perceived as an unusual or worrisome source of FDI. In fact, up until the time of the global financial crisis of 2008, Chinese investment was not a relevant factor for Europe in terms of size. ${ }^{21}$ During and after the crisis, however, muchneeded capital injections for struggling European economies, also in sensitive sectors and strategically important firms, became a welcome revenue source from a booming Chinese economy. Some observers have consequently described the increase of Chinese investment into Europe as exponential since 2008. ${ }^{22}$ Figure 1 shows this trend over the last decade. Whereas stocks are steadily increasing, flows peaked around 2016 when backlash against CSLI in major European economies started to gain material traction as we document in this paper.

\footnotetext{
${ }^{20}$ Karel van Miert, "What Does a Level Playing Field Mean in the Global Economy?," European Commission, (1998), https://ec.europa.eu/competition/speeches/text/sp1998_031_en.html.

${ }^{21}$ Meunier, "Chinese Direct Investment in Europe."

22 Meunier, "Chinese Direct Investment in Europe."
} 


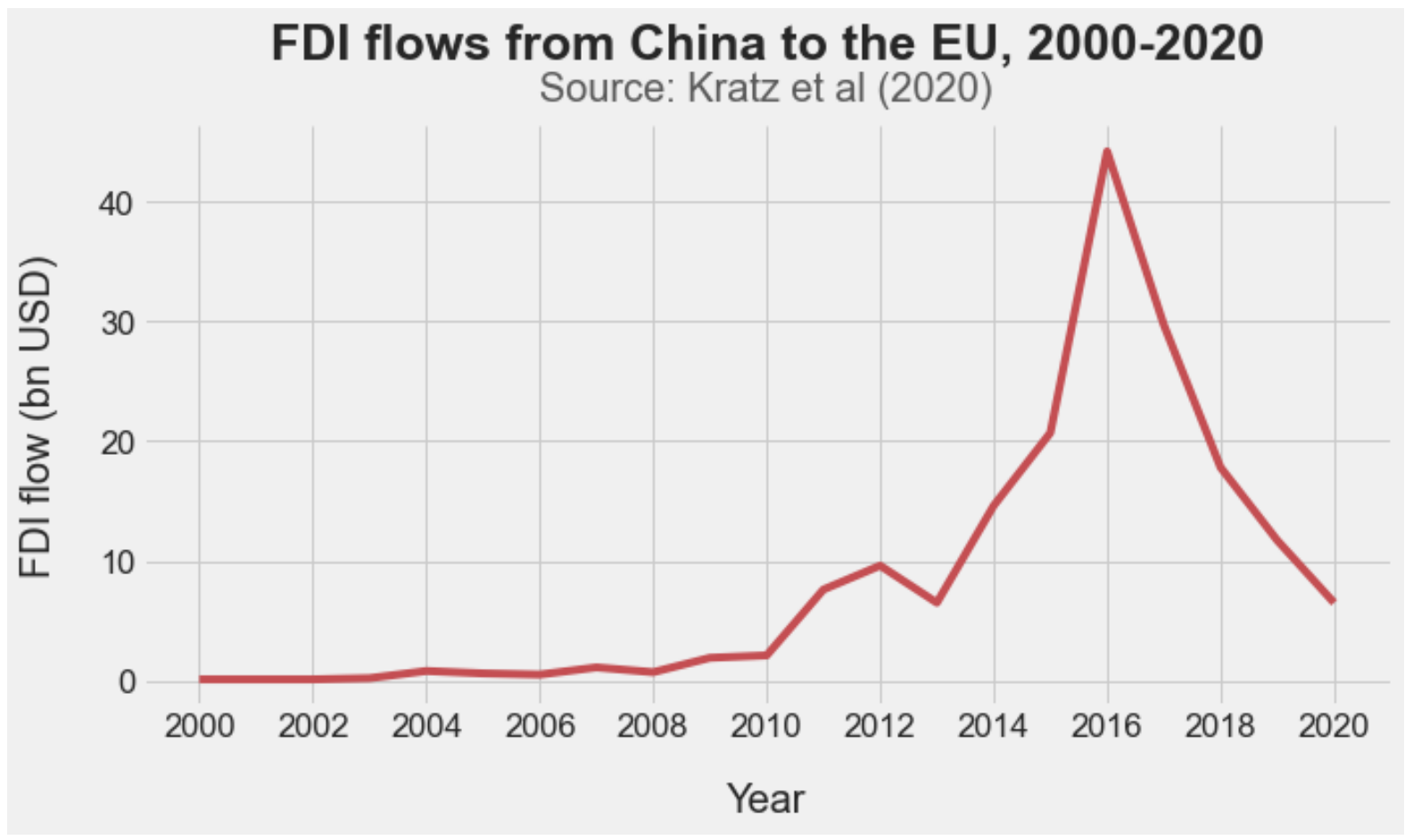

Figure 1: Inflow of Chinese FDI into Europe between 2000 and 2020 (in bn USD).

This growth was not exclusively based on state-led investment, but CSLI played a major role in most large-scale and headline-making news. As described above, the close coordination between Chinese outward FDI (both private and state-led) also made the distinctions between different forms of Chinese capital difficult. This distinction does also not play a central role in the actual governance of Chinese OFDI. ${ }^{23}$ The political discussion in European countries such as the UK or Germany also tends to collapse "private" and "state-led" forms of Chinese investment in favor of understanding Chinese investment as being at least closely tied to state interests:

"The clear conclusion [...] is that with the exception of micro-level and smaller companies - so anything from medium-sized companies upwards - Chinese companies cannot really be regarded as private in the sense that is understood in liberal market economies." 24

\footnotetext{
${ }^{23}$ Sophie Meunier, "A Faustian Bargain or Just a Good Bargain? Chinese Foreign Direct Investment and Politics in Europe," Asia Europe Journal Vol. 12, No. 1-2 (2014), 143-58, here: p. 147. Another distinction that plays a role for CSLI in general (but not necessarily for its perception abroad) is between locally and nationally owned SOES. The latter enjoy on average higher status, more resources, and political capital than the former, see Ching Kwan Lee, The Specter of Global China: Politics, Labor, and Foreign Investment in Africa (Chicago: The University of Chicago Press, 2017), p. 4.

${ }^{24}$ Interviewee 09; see also Interviewee 04.
} 
The increasing presence of CSLI after the financial crisis then raised questions in public and academic discussions about the benefits, drawbacks, and possible "strings attached" of Chinese investment ${ }^{25}$ - especially in high-tech and other sensitive sectors. ${ }^{26}$ Beyond Europe, countries like the US or Australia experienced similar discussions about Chinese FDI at this time. ${ }^{27}$ This trend was exacerbated by the announcement of the "Made in China 2025" (MiC 2025) industrial strategy in 2015. By investing abroad, Chinese (state-led) companies acquire technological know-how and assets that can help them to move up global value chains and propel domestic development in the sense of MiC 2025. ${ }^{28}$ CSLI into European countries like Germany has been found to be predominantly targeting the key tech and knowledge sectors that the Chinese State Council designated as relevant for the MiC 2025 strategy. ${ }^{29}$ Europe hence became a relevant investment target for developmental CSLI over the last decade. ${ }^{30} \mathrm{We}$ describe the emerging political backlash as the China-effect in the next section.

The China-effect: How do we know it when we see it?

\section{Concepts and Mechanisms}

The rise of China as a state-led investor in Europe raises skepticism and defensive attitudes in major host countries as well as in the EU itself. Figure 1 shows a clear subsiding of CSLI flows into Europe after 2016, which has also to do with the political backlash we theorize in this paper. We argue that such reactions are not only anecdotal or temporary, but that they reflect

\footnotetext{
${ }^{25}$ Meunier, "A Faustian Bargain or Just a Good Bargain?."

${ }^{26}$ See Zenobia T. Chan and Sophie Meunier, "Behind the Screen: Understanding National Support for a Foreign Investment Screening Mechanism in the European Union," The Review of International Organizations (2021), online first; Sean Kenji Starrs and Julian Germann, "Responding to the China Challenge in Techno-nationalism: Divergence between Germany and the United States," Development and Change Vol. 52, No. 5 (2021), pp. 1122-46.

27 James Reilly, "Counting On China? Australia's Strategic Response to Economic Interdependence," The Chinese Journal of International Politics Vol. 5, No. 4 (2012), pp. 369-94; Dustin Tingley, Christopher Xu, Adam Chilton, and Helen V. Milner, "The Political Economy of Inward FDI: Opposition to Chinese Mergers and Acquisitions," The Chinese Journal of International Politics Vol. 8, No. 1 (2015), pp. 27-57.

28 Jost Wübbeke, Miriam Meissner, Max. J. Zenglein, Jaqueline Ives, and Björn Conrad, "Made in China 2025. The Making of a High-Tech Superpower and Consequences for Industrial Countries," Merics Papers on China, (2016), https://merics.org/sites/default/files/2020-04/Made\%20in\%20China\%202025.pdf.

${ }^{29}$ Cora Jungbluth, Kauft China systematisch Schlüsseltechnologien auf? Chinesische Firmenbeteiligungen in Deutschland im Kontext von „Made in China 2025“ (Global Economic Dynamics. Gütersloh: Bertelsmann Stiftung, 2018).

30 Jeffrey Henderson and Mike Hooper, "China and European Innovation. Corporate Takeovers and Their Consequences," Development and Change Vol. 52, No. 5 (2021), pp. 1090-21.
} 
a more fundamental ideational change taking place over the last decade. The ideas of policymakers in major, technology-rich European economies incrementally transformed over this period from a relatively open or neutral position towards relatively protectionist stances (Figure 2). Consequently, issues of national security often outweigh the imperatives of investment attraction from particular sources (namely China). We hypothesize that the rise of CSLI in sensitive sectors is the major independent variable causing this shift over time. Figure 3 summarizes this argument theoretically. We first describe the independent, dependent and mediating variables of our mechanism, and subsequently delineate the theorized mechanism itself.

(1)
Country X
Open for CSLI

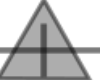
Closed for CSLI
Neutral

(2)

\section{Country $\mathrm{X}$}

Open for CSLI

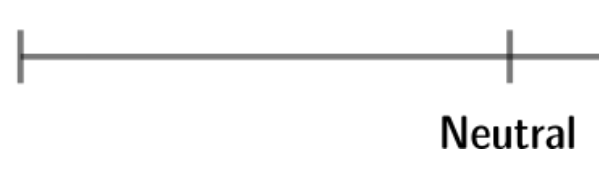

Figure 2: Theoretical change of openness of investment regimes for CSLI over time. (1) Depicts the situation after the GFC, (2) at the end of the decade (2020).

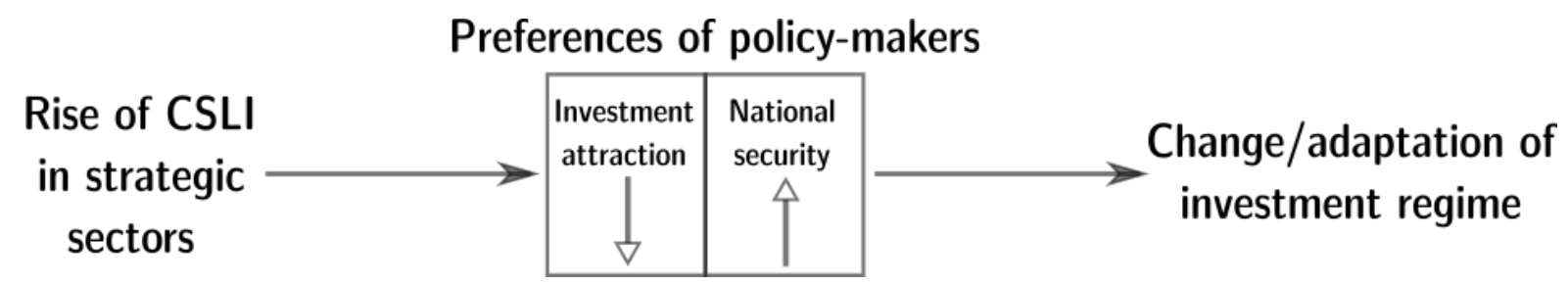

Figure 3: Simplified model of the process of incremental policy-change we postulate for the rise of CSLI. 
We take the rise of CSLI into politically sensitive or strategic sectors as our independent variable (IV). ${ }^{31} \mathrm{CSLI}$ is in our conceptualization not restricted to immediately state-owned, but to statecontrolled Chinese investment in the broadest sense. We derive this conceptualization from three major insights of the literature on Chinese investment into Europe: first, China has been growing quickly over the last decade as major investor into Europe, as various studies documented over the last years. ${ }^{32}$ Second, this investment is to a large degree consisting of state-owned or private, but in any case state-directed or state-led capital, which is de facto governed in the same manner. ${ }^{33}$ By using "state-led" investment as an umbrella term instead of simply "state capital", we build on and nuance Ching Kwan Lee's ideal-typical distinction between state capital that "serves interests defined by a sovereign state", and private capital that "serves those [interests] of the shareholders". ${ }^{34}$ The concept of CSLI shifts the focus away from the sender (states or private shareholders) towards the targets (here: European states) of this investment. As we argue in the previous section, state and private Chinese investment is in the perception of European policymakers often (and de facto) not distinguishable. By using "state-led", we hence emphasize, following Lee, the "Janus face" of CSLI in the perception of the investment targets, be it nominally state-owned or not. Third, Chinese outward investment is, on average, controlling investment, which means that CSLI aims in general at acquiring whole firms or at least majority-stakes in its host countries. ${ }^{35}$ This is important in order to understand the protectionist backlash we describe below. It is not "passive" portfolio investment from China that causes political reverberations, but the large-scale investments

\footnotetext{
${ }^{31}$ First, by 'rise' we do not only refer to total investment inflows, but also to the build-up of investment stocks, which have been considerable in the last decade in both of our cases (see Figures 4 and 5 in the next section). The increasing presence of CSLI is hence not necessarily dependent on yearly rising inwards FDI from China, but builds up over time as long as there are net positive inflows. Second, what makes a sector, sensitive' or ,strategic' also crucially depends on the perceptions of policymakers and other societal actors at a given point in time, see Chan and Meunier, "Behind the Screen." Here, we understand sensitive/strategic sectors either as critical infrastructure (telecom networks, energy security, logistics networks, and the like) or as industries containing knowledge and assets that are important for global technological and industrial competition such as robotic firms, niche firms in the semiconductor business, or other geoeconomically relevant industries.

${ }^{32}$ See for example Agatha Kratz, Mikko Huotari, Thilo Hanemann, and Rebecca Arcesati, "Chinese FDI in Europe: 2019 Update" Merics Papers on China, (2020), https://rhg.com/wp-content/uploads/2020/04/MERICSRhodium-Group COFDI-Update-2020-2.pdf; Meunier, "Chinese Direct Investment in Europe."

${ }^{33}$ Thilo Hanemann, "Chinese Direct Investment in the EU and the US: A Comparative View," Asia Europe Journal Vol. 12, No. 1-2 (2014), pp. 127-42; Le Corre, "Chinese Investments in European Countries. "; Haiyan Zhang and Daniel Van Den Bulcke, "China's Direct Investment in the European Union: A New Regulatory Challenge?," Asia Europe Journal Vol. 12, No. 1-2 (2014), pp. 159-77.

${ }^{34}$ Lee, The Specter of Global China, p. 4.

${ }^{35}$ Milan Babic, Javier Garcia-Bernardo, and Eelke M. Heemskerk, "The Rise of Transnational State Capital: StateLed Foreign Investment in the 21st Century," Review of International Political Economy Vol. 27, No. 3 (2020), pp. $433-75$.
} 
and takeovers of UK and German firms. Here it is particularly technology and knowledge-driven firms and assets that promise to propel Chinese domestic development and competitiveness and which are therefore especially sensitive targets for CSLI influx. ${ }^{36}$ Similarly, critical national infrastructure represents a politically problematic target for CSLI, where large and competitive Chinese energy and telecom infrastructure firms are seeking to gain shares in foreign markets. ${ }^{37}$ The rise of CSLI thus refers to the accelerated presence of such Chinese state-owned investment forms in European countries since 2008. ${ }^{38}$

Our dependent variable (DV) is the degree of change of national investment regimes that restrict foreign investment in general, and CSLI in particular. We understand a national investment regime as the collective legal rules that govern inward and outward investment of or into a country. ${ }^{39}$ Logically, we focus on those parts of national investment regimes that govern inward investment. The EU and European countries have been very open to foreign investment in general and CSLI in particular for a longer time period. ${ }^{40}$ This stance is now changing, and our focus in this paper is especially on investment screening mechanisms as the protectionist tool of choice for the EU and many European countries. While investment screening might also be interpreted as a rather "soft" tool of governing inwards investment, ${ }^{41}$ we still understand it to be a qualitative shift from a mostly open European economy towards stronger protectionism..$^{42}$ The fact that most European countries choose to escalate screening mechanisms, while maintaining a certain degree of traditional openness, speaks to its

\footnotetext{
${ }^{36}$ Chan and Meunier, "Behind the Screen."

${ }^{37}$ Andrew Stephen Campion, "From CNOOC to Huawei: Securitization, the China Threat, and Critical Infrastructure," Asian Journal of Political Science Vol. 28, No. 1 (2020), pp. 47-66.

${ }^{38}$ We include both, green-and brownfield investment in our definition of CSLI. ,Classical' brownfield investment is closer to asset-grabbing, as it involves the acquisition of already existing assets. However, greenfield investment can also cause political reverberations, especially when it targets sensitive infrastructure like we describe especially in the UK case. Greenfield investment like from Huawei in the early 2010s is a case in point, since it targeted critical telecoms infrastructure. We thank an anonymous reviewer for bringing this up.

${ }^{39}$ See, e.g., Steve Browning and Oliver Bennett, "National Security and Investment Bill 2019-21," House of Commons (2021), https://researchbriefings.files.parliament.uk/documents/CBP-8784/CBP-8784.pdf.

40 Zhang and Van Den Bulcke, "China's Direct Investment in the European Union."

${ }^{41}$ See, e.g., Stephan W. Schill, "The European Union's Foreign Direct Investment Screening Paradox: Tightening Inward Investment Control to Further External Investment Liberalization," Legal Issues of Economic Integration Vol. 46, No. 2 (2019), pp. 105-28.

${ }^{42}$ See for example Sarah Bauerle Danzman and Sophie Meunier, "The Big Screen: Mapping the Diffusion of Foreign Investment Screening Mechanisms," SSRN Working Paper (2021), https://ssrn.com/abstract=3913248, who trace the evolution of investment screening mechanisms globally and note a proliferation, broadening (of sector coverage), lowering of review thresholds and a convergence in policy implementation. All four aspects point to a rise and exacerbation of investment screening as an economic policy tool.
} 
interpretation as an increasing protectionism of European investment regimes. We trace the changes of two of these regimes (in the UK and Germany) over time as our dependent variable.

In this context, the changes of preferences of policymakers represent our mediating variable (MV). This is the core mechanism connecting the rise of CSLI in strategic sectors with the palpable changes in investment regimes in recent years; and also our empirical focus in this paper. Essentially, policymakers have to weigh to what extent CSLI is a "good bargain" that increases domestic welfare, and to which extent its targeting of sensitive sectors infringes national security and is thus rather a "Faustian bargain". ${ }^{43}$ We argue that this weighting process is leaning more towards the side of national security the more, ceteris paribus, CSLI builds up in strategic sectors. Policymakers hence undergo an incremental ideational change that affects their preferences over time. These preferences, we argue, are complex and not reducible to the simple choice between attracting or blocking investment. We thus do not claim that the choice between attracting CSLI for economic benefit and blocking it for national security reasons is a categorical one. In fact, tools like investment screening allow governments precisely to be more nuanced and decide on a case-by-case basis about specific transactions. ${ }^{44}$ At the same time, we hold that, after 2008, policy-makers in advanced European economies faced the basic choice between maintaining the status quo of a mostly open economy, or to tighten the screws based on the consideration that specific forms of foreign investment infringe national security in the broadest sense. This weighting process that re-appreciates the latter aspect is what we claim as change of preferences, because it incrementally changes the character of European investment regime(s).

For our mediating variable, two clarifications are important. The first is that by "policymakers", we refer to governmental actors being influential in policy-making processes over the last decade. While the specific actors can change, policy processes themselves are usually complex and long-winded. ${ }^{45}$ This makes those processes more "sticky" than the particular actors, allowing us to trace them over time. In addition, both our empirical cases have retained the same governing party in power since 2010, which adds to the stability argument. The second clarification concerns the preferences of policy-makers over time. We draw on theories

\footnotetext{
${ }^{43}$ Meunier, "A Faustian Bargain or Just a Good Bargain?."

${ }^{44}$ Sarah Bauerle Danzman, "Investment Screening in the Shadow of Weaponized Interdependence," in Daniel W. Drezner, Henry Farrell, and Abraham L. Newman, eds., The Uses and Abuses of Weaponized Interdependence (Washington: Brookings Institution Press, 2021), pp. 257-72; Interviewee 09.

45 Paul A. Sabatier, ed., Theories of the Policy Process (Boulder, CO: Westview Press, 2007).
} 
of incremental ideational change to conceptualize how these preferences are being slowly transformed since $2008 .{ }^{46}$ Such an approach challenges the common understanding of ideational change in institutional theory as events that trigger sudden institutional transformation, most often in times of crisis. ${ }^{47}$ The rise of CSLI and the changing nature of globalization are not typical crisis moments that initiate sudden ideational and consequently institutional change. ${ }^{48}$ Rather, both are long, complex processes that are accompanied by the tentative and incremental adjustment of perceptions of policy-makers. This means that we do not look at large-scale, paradigmatic changes, but rather at transformations within existing political economy frameworks. This forces us to develop a precise empirical focus in order to excavate and trace changes on the ideational level which are not part of grand political and ideological debates.

How do these variables interact within our mechanism? We identify two steps that lead to the outcome we describe above. First, the rise of CSLI in strategic sectors (IV) pushes policymakers to rethink the weighting between investment attraction and national security in favor of the latter. During the early days after the GFC, CSLI started to become a major factor in European political economies, but did not immediately amount to significant volumes. With time, the stock of CSLI in general, and in sensitive sectors in specific, started to grow and cause discussions about the benefits and drawbacks of such investment. The increase of CSLI volumes in sensitive sectors and the accompanying discourse shifts led policymakers to increasingly rethink their initial (post-GFC) weighting that strongly privileged investment attraction over national security concerns. As we document in the next section, we hold this process to be of an incremental and escalatory nature. Second, the outcome of this incremental preference change constitutes our MV, which then translates, with some time lag, into a change or adaptation of the respective (national) investment regime. While this legal adaptation is not identical with mere preference change, we deem the former a "hard" indicator for the latter. An investment regime change without a preceding preference change of policymakers can logically only happen if there is a fundamental replacement of governing personnel (i.e. through an ousting of the incumbent government) or a situation where policymakers are

\footnotetext{
${ }^{46}$ Carstensen, "Ideas Are Not as Stable as Political Scientists Want Them to Be,"; Moschella, "The Institutional Roots of Incremental Ideational Change."

47 See, e.g., Hall, "Policy Paradigms, Social Learning, and the State."

48 Blyth, Great Transformations.
} 
forced somehow into legislative changes over a sustained period of time (in our case almost a decade). The former explanation does not pertain to our two cases (see the next subsection) and the latter explanation is highly unlikely. Once an investment regime changes, we can hence assume that a widely supported preference change among policy makers took place. Since this second part of our mechanism is a logically robust relation between the MV and the DV, we focus our empirical study on the first part, namely the explanation of the link between IV and MV.

\section{Research design and methods}

This empirical focus consists of a comparative case study, in which we analyze the effect of the rise of CSLI on policy makers' perceptions over the last decade. We compare Germany, a CME, with the UK, a LME, as two dissimilar cases in the comparative capitalisms research tradition, in order to increase the explanatory power of our argument. The time period of analysis starts with the Great Recession in 2008-2009. This event triggered an influx of state-owned capital in large Western economies, of which a significant part was Chinese. While evaluations of foreign state investment were fairly positive in some countries in the aftermath of the crisis, this changed over time. We trace this process of ideational change until today.

Both cases are important targets for foreign state-led and especially Chinese investment. In 2018, they ranked as the top two receivers of state-led investment, with both receiving well over 10 per cent of total global investment. ${ }^{49}$ Furthermore, both belong to the long-standing "big three" destinations of Chinese FDI in Europe. ${ }^{50}$ In fact, they attracted the most (UK) and the second most (Germany) cumulative FDI value from China over the last two decades. ${ }^{51}$ In both countries, the political discussion and politicization of CSLI has been high in recent years, with landmark investments and failed takeover attempts in strategic sectors creating heated debate about the status of CSLI for both economies. An additional benefit of both cases is that the major governing party has been consistent since 2010 (UK), and respectively 2005 (Germany). Both the Conservative Party (UK) and the Christian Democrats (CDU) (Germany) ruled in changing coalitions, but remained the dominant party and consequently shaped government policy decisively. Comparing these high-profile cases allows

\footnotetext{
${ }^{49}$ Babic et al., "The rise of transnational state capital."

50 Kratz et al., "Chinese FDI in Europe," p. 10.

${ }^{51}$ Kratz et al., "Chinese FDI in Europe," p. 11.
} 
us to generate in-depth insights that can in a next step be generalized and leveraged for further theory-building and -testing.

We rely on newspaper articles, official documents, policy papers, and other types of written statements from this period. We also conducted ten expert interviews in both countries with parliamentarians, think tanks, and industry associations in early 2021 (see supplemental file). Together, our collected data allows us to reconstruct the incremental ideational change among policy-makers in the two countries since 2008 , which led to a change of both investment regimes driven by the rise of CSLI at the end of the decade.

Methodologically, our account borrows major elements from ideational processtracing. ${ }^{52}$ In line with this approach, we contribute important building blocks for "identify[ing] the intervening causal process - the causal chain and causal mechanism - between an independent variable (or variables) and the outcome of the dependent variable". ${ }^{53}$ We adhere to the quality criteria of process tracing research by delineating the research design explicitly and operationalizing our mechanisms (section "The China-effect"), discussing alternative explanations (section "Discussion"), and providing a comprehensive research agenda (section "Conclusion"). ${ }^{54}$ At the same time, we emphasize the co-constitutive nature of ideational and material processes ${ }^{55}$, which is why our case may not be regarded as a pure instance of ideational causation as theorized in the process-tracing literature. ${ }^{56}$ Our operationalization makes it clear that we hypothesize a material process (the rise of CSLI) interacting over a longer timespan with existing ideas about foreign investment, and thereby causing a shift towards stricter investment screening mechanisms. We analyze this co-constitution of material and ideational change with the described toolbox from the process-tracing literature.

Measuring this co-constitutive process directly is difficult, because much of it takes place in ministries and other government bodies, which are difficult to access per se. Furthermore, ideas about specific types of investment like CSLI are not easy to distinguish

\footnotetext{
52 Andrew Bennett and Jeffrey T. Checkel, eds., Process Tracing: From Metaphor to Analytic Tool (Cambridge: Cambridge University Press, 2014); Jeffrey T. Checkel, "Process Tracing and International Political Economy," in Jon C. W. Pevehouse and Leonard Seabrooke, eds., The Oxford Handbook of International Political Economy (Oxford University Press, 2021); Alexander L. George and Andrew Bennett, Case Studies and Theory Development in the Social Sciences (Cambridge, Mass: MIT Press, 2005).

${ }^{53}$ George and Bennett, Case Studies and Theory Development, p. 206.

54 See Checkel, "Process Tracing and International Political Economy."

${ }^{55}$ See also Lukas Linsi, "The Discourse of Competitiveness and the Dis-Embedding of the National Economy," Review of International Political Economy Vol. 27, No. 4 (2020), pp. 855-79, here: p. 857.

${ }^{56}$ Alan M. Jacobs, "Process Tracing the Effects of Ideas," in Andrew Bennett and Jeffrey T. Checkel, eds., Process Tracing: From Metaphor to Analytic Tool (Cambridge: Cambridge University Press, 2014), pp. 41-73, here: p. 44.
} 
methodologically from related and more general ideas about foreign investment or the general "investment climate" of an economy. ${ }^{57}$ We hence approach this interaction and coconstitution of material and ideational factors methodologically by integrating different methodological elements of ideational studies ${ }^{58}$ : By triangulating the textual data we gather from policy documents, newspapers, and reports with expert interviews, we ensure to adequately capture the nuances of these ideational changes. Our dependent variable - the changing investment regimes - adds further leverage to the argument, since these "material" changes require a preceding change in the ideas and preferences of policy-makers.

From embracing to protectionism: Ideational change toward CSLI in the UK and Germany 2008-2020

UK: From "open to business" to new geoeconomic realities

\section{After the crisis: CSLI attraction in the "golden era"}

The UK was hit particularly hard by the GFC due to the relatively high exposure of the financial sector to the global financial system. The costs of bank bailouts as a share of GDP were the second largest in the EU, on top of further massive crisis expenditures. ${ }^{59}$ The new Conservative government that took over in May 2010 embarked on an austerity path that reduced the budget deficit, but also severely impaired growth potential by suppressing domestic investment. In this situation, foreign capital was a welcome source of investment in austere times. Consequently, the Cameron government announced at its inception that investment attraction was a top priority, thereby even trying to "reorientate the Foreign Office to be much more commercially minded" ${ }^{60}$

\footnotetext{
57 See Linsi, "The Discourse of Competitiveness and the Dis-Embedding of the National Economy."

58 Marij Swinkels, "How Ideas Matter in Public Policy: A Review of Concepts, Mechanisms, and Methods," International Review of Public Policy Vol. 2, No. 3 (2020), pp. 281-316.

${ }^{59}$ Emiliano Grossman and Cornelia Woll, "Saving the Banks: The Political Economy of Bailouts," Comparative Political Studies Vol. 47, No. 4 (2014), pp. 574-600, here: p. 581.

60 BBC, "David Cameron Focuses on Foreign Trade Policy," BBC News, 22 July, 2010,

https://www.bbc.com/news/uk-politics-10722283.
} 
(A)

\section{FDI from China to UK, 2010-2020}

Source: AEI China Investment Tracker

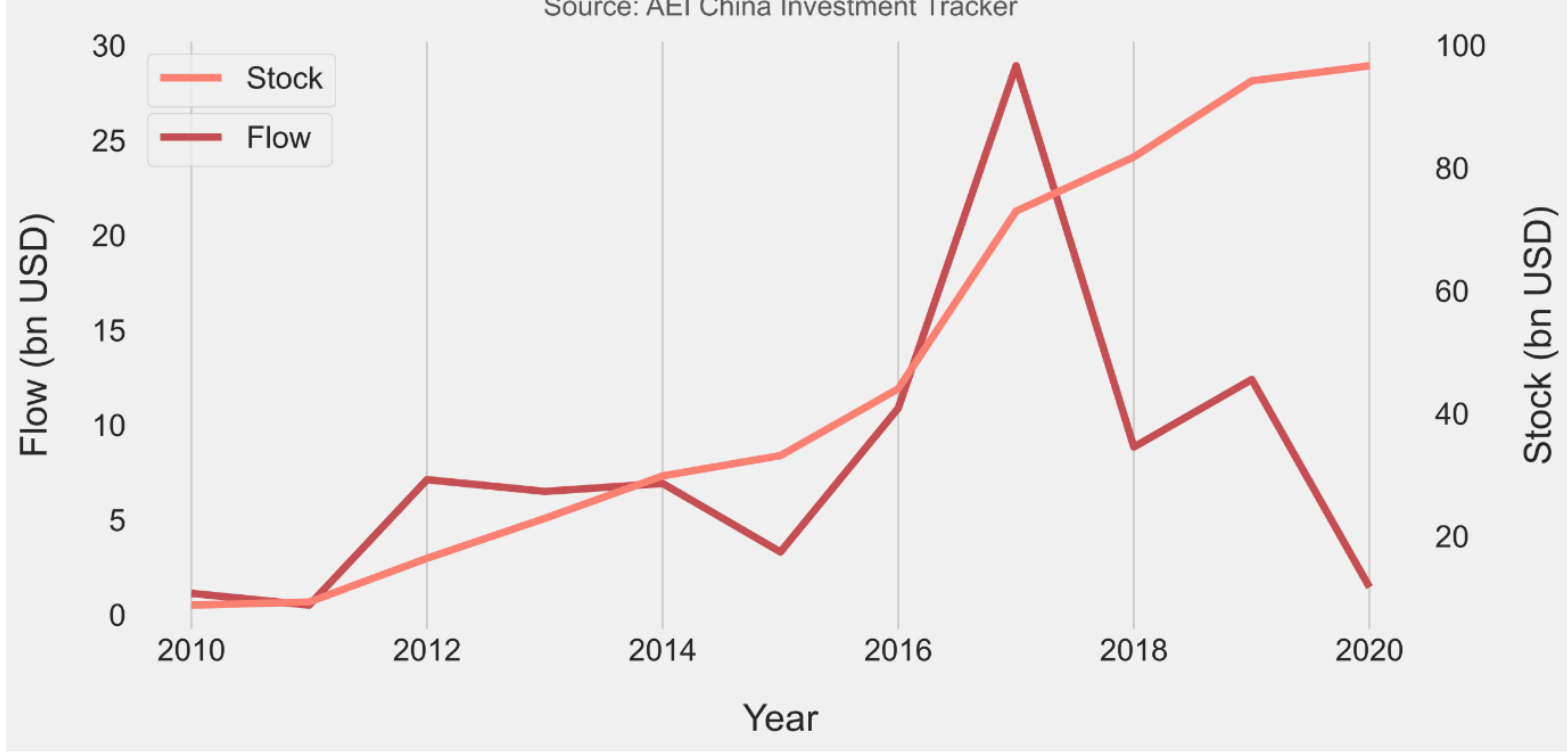

(B)

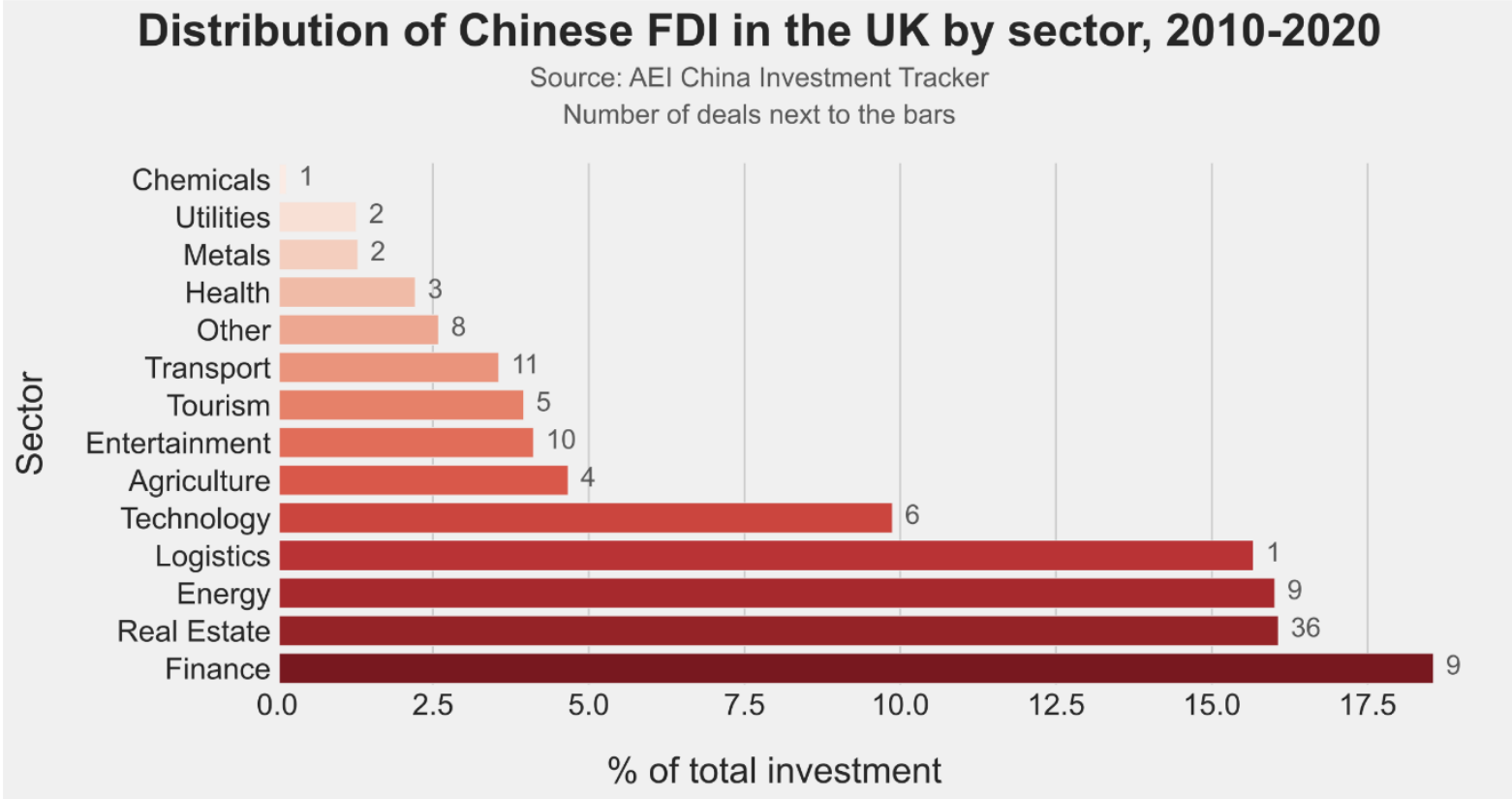

Figure 4: (A) Flows and stocks of Chinese FDI in the UK from 2010 to 2020 (in bn USD). (B) Distribution of Chinese FDI by sectors (in percent).

These efforts showed results over time, as the UK registered record FDI inflows in 2015 and 2016. Within its general investment attraction offensive, the government also specifically sought Chinese FDI, which was supposed to prop up ailing UK public infrastructure. Figure 4 
documents the impressive rise of Chinese FDI in the UK since 2010, with stocks growing more than 10-fold in the last decade. This supposed new "golden era"61 between China and the UK was inaugurated by the UK-China Energy Dialogue, which facilitated clean energy cooperation between both countries, including the expansion of nuclear energy and Chinese investment in it. State-owned entities like the China General Nuclear Power Group (CGN) quickly began to move into the UK market, for example by participating in the megaproject Hinkley Point C or in the Bradwell B project in Essex. ${ }^{62}$ Energy then became also one of the main sectoral targets of CSLI in the UK (Figure 4). Next to real estate and finance, which are large but often not strategically relevant, CSLI targeted also important technological industries like the Huaweiinvestment in 2013, which became highly controversial later in the decade (see the following). Overall, however, the strategic goal of attracting foreign investment in times of economic recovery and tight budgets in the post-crisis phase clearly outweighed possible drawbacks of CSLI and state-led investment in general in the beginning for the UK government.

\section{From 2014 to 2017: growing skepticism}

However, growing skepticism towards CSLI slowly emerged after the initial enthusiasm brought forward by the Cameron government. The Chinese entry into British nuclear power generation as a fundamental infrastructure of the UK economy soon led to political pushback. The May government that was formed in summer 2016 decided to delay the approval for Hinkley Point C over concerns about the involvement of the Chinese state via CGN. ${ }^{63}$ Government sources were reported to be searching for possibilities to back out of the project and cut ties with China over nuclear energy with an eye to energy security. ${ }^{64}$ After several months, Prime Minister May decided to move on with the project under tightened national security measures, including a de facto government veto possibility in the future. ${ }^{65}$ The stalling and review of the project

\footnotetext{
${ }^{61}$ Reuters, "China, Britain to Benefit from 'golden Era' in Ties," Reuters World News, 18 October, 2015, https://www.reuters.com/article/us-china-britain-idUSKCNOSB10M20151017.

62 ECIU, "China and UK Nuclear Power," Energy and Climate Intelligence Unit, (2020), https://eciu.net/analysis/briefings/uk-energy-policies-and-prices/china-and-uk-nuclear-power.

63 Graham Ruddick, "Why Have Ministers Delayed Final Approval for Hinkley Point C?," The Guardian, 29 July, 2016, https://www.theguardian.com/uk-news/2016/jul/29/hinkley-point-c-why-has-government-delayed-finalapproval.

64 Joe Watts, "Hinkley Point Nuclear Power Station: Whitehall Officials 'Exploring Ways UK Could Pull out of Deal,'” The Independent, 24 August, 2016, https://www.independent.co.uk/news/uk/politics/hinkley-point-edfnuclear-power-station-deal-how-uk-could-pull-out-a7207776.html.

65 Sara Stefanini, "Theresa May Gives Hinkley the Green Light," Politico, 15 September, 2016, https://www.politico.eu/article/uk-has-approved-hinkley-with-conditions-report/\#.
} 
foreshadowed further conflicts later in the decade regarding CSLI investment in critical infrastructures. At this point, incremental ideational change became already visible, especially in contrast to the early years of the Cameron government: critical infrastructure now became off-limits for CSLI, which had not been the case before. At the same time, observers evaluated the May government not as extremely or suddenly hawkish on China, rather as increasingly less enthusiastic compared to the Cameron government. ${ }^{66}$

The CSLI inflows were still rising at the time, and the respective stock of investment grew rapidly between 2014 and 2018. In line with our argument, the inflow of a chunk of this investment into critical infrastructure clearly triggered the growing skepticism we observe around this time. UK security services issued warnings precisely relating to the finalization of the Hinkley Point $\mathrm{C}$ deal under Cameron, which led conservative policymakers to immediately raise the question of national security in late $2015 .{ }^{67}$ The later chief of staff of Theresa May captured the incremental ideational change at the time by qualifying the nuclear deal with CGN as "[o]f course we should seek to trade with countries right across the world - but not when doing business comes at the expense of Britain's own national security". 68 This balancing was also reflected in the initial hesitation and then conditional approval of the project by the May government, aiming to avoid a full-fledged confrontation with China, while developing a hard line on critical infrastructure investment by CSLI. ${ }^{69}$

Further skepticism towards CSLI was in the making during this period. Concerns about telecom infrastructure provider Huawei were increasingly discussed publicly. The company's obscure ownership situation was a key issue, whereby studies claim Huawei to be at least a state-controlled, if not a fully state-owned entity. ${ }^{70}$ Amid growing concerns, the company decided to create a UK-based facility which would scrutinize possible security risks of its products and report directly to the UK government. While this Huawei Cyber Security

\footnotetext{
${ }^{66}$ Interviewee 09.

67 Sean O'Neill, Deborah Haynes, and Robin Pagnamenta, "Nuclear Deal with China Is Threat to UK Security," The Sunday Times, 16 October, 2015, https://www.thetimes.co.uk/article/nuclear-deal-with-china-is-threat-to-uksecurity-jv7xnh975vj.

68 Nick Timothy, "The Government Is Selling Our National Security to China," Conservative Home, 20 October, 2015, http://www.conservativehome.com/thecolumnists/2015/10/nick-timothy-the-government-is-selling-ournational-security-to-china.html.

69 Stefanini, "Theresa May Gives Hinkley the Green Light."

${ }^{70}$ Christopher Balding and Donald C. Clarke, "Who Owns Huawei?," SSRN Working Paper, (2019), https://papers.ssrn.com/sol3/papers.cfm?abstract_id=3372669.
} 
Evaluation Centre (HCSEC) worked mostly under the public radar, its oversight board started to release annual public reports in 2015. The goal of the reports is to document efforts "to mitigate any perceived risk arising from the involvement of Huawei in parts of the UK"s critical infrastructure".$^{71}$ The first reports, published during the tenure of the Cameron government, did not detail any major security concerns. This changed significantly during 2017-2018 and the following period of stronger scrutiny towards CSLI, as we documented above.

\section{From 2017 onwards: the rise of the new protectionism}

These first cracks in the fairly open inwards FDI regime were the prelude to a transformed approach of the UK government vis-à-vis CSLI after 2017. In October, it presented a green paper entailing a review of the national security implication of foreign ownership in critical UK assets. ${ }^{72}$ The paper proposed a new investment regime that would go significantly beyond the existing foreign investment review mechanism in the UK (the National Enterprise Act of 2002). The report explicitly refers to the Hinkley Point C controversy of the previous year as a motivating factor for this review. ${ }^{73}$ We take these references as strong indicator for the incremental ideational change we theorized in the previous section. While the report does not single out a particular investor or state as potential security threat, the reference to this controversial episode of CSLI is telling. In accordance with this, our interviewees explained that CSLI is perceived to be the main driver behind ideational change among UK policy-makers ${ }^{74}$, with Russian state-led investment also being a relevant, but smaller factor: ${ }^{75}$

\footnotetext{
"I think the current concern is mainly about corporations from China. There is concern about inward FDI from State Owned Enterprises (SOEs), but it is believed that senior managers of Chinese non-SOES have links with the Communist Party of China." ${ }^{\prime 76}$
}

\footnotetext{
${ }^{71}$ HCSEC, "Huawei Cyber Security Evaluation Centre Oversight Board Annual Report," Huawei Cyber Security Evaluation Centre, (2018), https://assets.publishing.service.gov.uk/government/uploads/system/uploads/attachment_data/file/727415/20 180717_HCSEC_Oversight_Board_Report_2018_-_FINAL.pdf, here: p. 2.

72 UK Government, "National Security and Infrastructure Investment Review Green Paper," Department for Business, Energy \& Industrial Strategy, 17 October, 2017, https://assets.publishing.service.gov.uk/government/uploads/system/uploads/attachment_data/file/652505/20 17_10_16_NSII_Green_Paper_final.pdf.

73 UK Government, "National Security and Infrastructure Investment Review Green Paper," p. 6.

74 Interviewee 01; 02; 04; 09.

75 Interviewee 03; 04.

${ }^{76}$ Interviewee 04.
} 
The 2002 law aimed at improving competition lawmaking and reducing monopolistic tendencies in UK markets through better scrutinizing mergers and acquisitions (M\&As). For this task, different government bodies received additional powers to investigate and penalize anti-competitive behavior. The act was, as such, not created on the basis of national security concerns, but rather motivated by prevailing competitiveness issues at the time. We can hence see that superficially similar policy-projects are driven by significantly altered preferences of policy-makers regarding investment attraction and national security.

The green paper took hence a different, clearly national security-oriented approach. It suggested to lower some of the thresholds for government examination of M\&As in the short run $^{77}$ and to overhaul the whole foreign investment screening regime in the long run. This second aspect asks to substantially broaden the range of transactions which the government is allowed to examine, and to introduce a "mandatory notification regime" 78 for future, politically sensitive investment projects. The May government did not communicate this as only cosmetic adjustments of existing measures, but explicitly called for a "new regime"79 incorporating national security as a major variable in it. Importantly, the paper also names a changed global landscape, involving more risks to national security, as a major reason for a new approach to foreign investment. ${ }^{80}$ However, the concrete policy-changes are conducted in the FDI regulation domain, which points to the specific role that CSLI plays for increased protectionism - embedded in broader geopolitical sea changes. We discuss this point and alternative explanations in the "Discussion" section.

After the initiation of this legislative process, the public discourse about CSLI intensified. In 2018, a new bid by CGN to extend its ownership in UK nuclear plants beyond Hinkley Point C to eight other sites faced a strong political headwind. Observers identified the UK's openness to Chinese state-led takeovers of critical infrastructure as an outlier compared to other OECD countries. ${ }^{81}$ In parallel, the Huawei watchdog HCSEC for the first time identified "shortcomings

\footnotetext{
77 This includes among others lowering the turnover thresholds for those deals from $£ 70 \mathrm{mn}$ to $\mathrm{f} 1 \mathrm{mn}$. See UK Government, "National Security and Infrastructure Investment Review Green Paper," p.7.

78 UK Government, "National Security and Infrastructure Investment Review Green Paper," p. 7.

79 UK Government, "National Security and Infrastructure Investment Review Green Paper," p. 7.

80 UK Government, "National Security and Infrastructure Investment Review Green Paper," p. 33.

${ }^{81}$ Adam Vaughan and Lily Kuo, "China's Long Game to Dominate Nuclear Power Relies on the UK," The Guardian, 26 July, 2018, https://www.theguardian.com/environment/2018/jul/26/chinas-long-game-todominate-nuclear-power-relies-on-the-uk; Zoe Wood, "China Looking to Buy Stake in UK Nuclear Plants, Say
} 
in Huawei's engineering processes" 82 , which would pose new long-term risks and challenges for the UK. The 2019 report then engaged in a full-scale criticism of Huawei's ability to remedy existing software engineering and cyber security problems, including a warning that the confidence in the company to not pose a national security risk is now limited. ${ }^{83}$ This report attracted widespread media attention for its "unusually direct criticism" 84 and elevated the dispute between the government and Huawei to a new level. Both developments are unprecedented discourse shifts in the public discourse on CSLI and reflect how the rise of CSLI in exactly these sensitive industries creates backlash which soon gets translated into policymaking in the form of a revised white paper on inwards investment regulation.

This white paper following the initial government proposal for a new foreign investment screening regime integrated the described developments into a more comprehensive approach. This incremental change is already visible in the title, which dropped the emphasis on infrastructure investment, but which simply referred to national security and investment per se. ${ }^{85}$ The paper put decisively more direct emphasis on potentially "hostile" actors and their direct connection to business ownership than the previous green paper, which in comparison remained fairly abstract. The discussions and developments around cases like Huawei and CGN contributed to incremental ideational change among British policy-makers. This changing stance had an effect on the clarity and resolution with which investment screening mechanisms were proposed. The proposal now asked to scrutinize each transaction leading to the acquisition of more than 25 per cent of the shares of an entity, more than 50 per cent of an asset, or any other (indirect) form of corporate control. With these changes, the UK moved closer to the foreign investment regimes of other OECD members, and hence incorporated some of the criticism of the UK as an international outlier. Within a changing

Reports," The Guardian, 8 July, 2018, https://www.theguardian.com/environment/2018/jul/08/chinainterested-majority-stake-uk-nuclear-power-stations-reports.

82 HCSEC, "Huawei Cyber Security Evaluation Centre Oversight Board Annual Report," here: p. 4.

83 HCSEC, "Huawei Cyber Security Evaluation Centre Oversight Board Annual Report," Huawei Cyber Security Evaluation Centre, (2019),

https://assets.publishing.service.gov.uk/government/uploads/system/uploads/attachment_data/file/790270/H CSEC_OversightBoardReport-2019.pdf.

84 Jack Stubbs and Cassell Bryan-Low, "Britain Rebukes Huawei over Security Failings, Discloses More Flaws," Reuters, 28 March, 2019, https://www.reuters.com/article/us-huawei-security-britain-idUSKCN1R90ZC.

85 UK Government, "National Security and Investment: A Consultation on Proposed Legislative Reforms," Department for Business, Energy \& Industrial Strategy, (2018),

https://assets.publishing.service.gov.uk/government/uploads/system/uploads/attachment_data/file/728310/20 180723_-_National_security_and_investment_-_final_version_for_printing_1_.pdf. 
global landscape, policy-makers see themselves clearly confronted with similar (national security) threats and choose to re-appreciate national security issues surrounding foreign investment.

After the publication of the white paper, a new government formation and the Brexit process delayed further steps, while the controversies around the mentioned issues did not stop. The outgoing May and the incoming Johnson government decided in April 2019 and January 2020, respectively, to allow Huawei only limited access to the "core" infrastructure of the $5 \mathrm{G}$ networks of the country. ${ }^{86}$ Furthermore, the tensions with CGN about the future of UK nuclear power grew more acute when a China-skeptic group of Conservative MPs pushed the government to cancel several nuclear plant building projects across the country. ${ }^{87}$ In autumn of 2020, news sources reported that the Johnson administration was planning to step in as shareholder in the Sizewell nuclear plant to replace Chinese state-owned CGN if necessary. ${ }^{88}$ The preliminary high point of these dynamics was the ultimate ban of Huawei from the UK 5G network at the end of 2020, as well as reports about plans of CGN to withdraw completely from the Sizewell nuclear project due to increasing pressure by conservative UK policymakers. ${ }^{89}$

Consequently, under the Johnson government, the incremental ideational and legal change of the UK regime had reached a clear inflection point by the end of 2020. In November 2020 a new Telecommunications Security Bill as well as the extensively discussed and now formulated National Security and Investment Bill were introduced. The former would give the government legal powers to monitor and intervene in existing and future use of technology and equipment by telecom providers. ${ }^{90}$ Similar to the process regarding the investment bill, potential state-based threats of foreign powers - as it played out in the Huawei case - remain

\footnotetext{
${ }^{86}$ Natasha Lomas, "UK Gives Huawei an Amber Light to Supply 5G," Tech Crunch, 24 April, 2019, https://techcrunch.com/2019/04/24/uk-gives-huawei-an-amber-light-to-supply-5g/.

87 Jonathan Ford, "UK's Reliance on China's Nuclear Tech Poses Test for Policymakers," Financial Times, 14 February, 2019, https://www.ft.com/content/7734e3be-2f6f-11e9-8744-e7016697f225.

88 Simon Jack, "UK Government Could Take Stake in Sizewell Nuclear Power Station," BBC News, September 16, 2020. https://www.bbc.com/news/business-54181748.

${ }^{89}$ Greg Ritchie, "China Considers Exiting U.K. Nuclear Plant Project: Daily Mail," Bloomberg, 12 December, 2020, https://www.bloomberg.com/news/articles/2020-12-12/china-considers-exiting-u-k-nuclear-plant-project-dailymail.

90 UK Government, "New Telecoms Security Law to Protect UK from Cyber Threats," Department for Digital, Culture, Media \& Sport, 24 November, 2020, https://www.gov.uk/government/news/new-telecoms-securitylaw-to-protect-uk-from-cyber-threats.
} 
the key rationale for this decision. The investment bill itself was widely perceived as a protectionist move of the UK. ${ }^{91}$ It also introduced confusion for lawmakers and investors around what "national security" really entails and whether this will not scare off potential future "clean" investments. ${ }^{92}$ During the third reading of the bill in the House of Commons, MPs emphasized that "we should not have a fixed definition of national security - we should have a framework for it". ${ }^{93}$ This framework, which would be an extension of the respective bill, could accordingly help the UK to fend off unwelcomed "cash from state-owned enterprises going around"94 and prevent "dangers [...] [like] some of the state-owned enterprises that are now sniffling around British businesses". ${ }^{95}$ Finally, a MP summarized the change in UK policymaking since 2010 by stating that the UK has for a long time been "profoundly naive and complacent about how we respond to the rise of China", and that the discussed legislative changes are "being introduced against that backdrop" .96 Our tracing of the process leading up to this bottom line provides evidence that CSLI in critical UK infrastructure drove and shaped this incremental ideational change in the last decade.

\section{Germany: from export champion to high-tech protectionism}

\section{After 2008: Between export addiction and rising protectionism}

Different from the UK, the solution of the economic problems of Germany after the GFC were not mainly about attracting investment, but about replacing depressed export markets. After European demand for German industrial goods collapsed, Chinese demand was crucial for salvaging the German export-dependent economy. ${ }^{97}$ While state-led investment into Germany grew and was also controversially discussed at the time ${ }^{98}$, CSLI was not a particular target in

\footnotetext{
91 Interviewee 01.

${ }^{92}$ Annabelle Timsit, "The UK Government Wants New Powers to Block Chinese and Other Foreign Takeovers," Quartz, 13 November, 2020, https://qz.com/1932426/national-security-and-investment-bill-prevents-foreigntakeovers-of-uk-firms/.

93 UK Parliament, "National Security and Investment Bill - Third Reading. Volume 687," House of Commons, 20 January, 2021, https://hansard.parliament.uk/commons/2021-01-20/debates/C02C7DD6-B739-438C-870535FOF3D942B2/NationalSecurityAndInvestmentBill\#, p. 1004.

94 UK Parliament, "National Security and Investment Bill," p. 1004.

95 UK Parliament, "National Security and Investment Bill," p. 1005.

96 UK Parliament, "National Security and Investment Bill," p. 1006.

97 Kundnani, Hans, and Jonas Parello-Plesner. "China and Germany: Why the Emerging Special Relationship Matters for Europe," ECFR Policy Brief, No. 55 (2012), pp. 1-16, here: p. 2.

98 Mark Thatcher and Tim Vlandas, "Overseas State Outsiders as New Sources of Patient Capital: Government Policies to Welcome Sovereign Wealth Fund Investment in France and Germany," Socio-Economic Review Vol. 14, No. 4 (2016), pp. 647-68, here: p. 653.
} 
these debates. One major reason for the neutral stance towards CSLI was the vital interest of the export-oriented German industry to maintain an open and symbiotic relationship with large export markets and investors like China. ${ }^{99}$ The result of this general openness was that CSLI could flow more or less unimpeded into Germany, peaking around 2016 (Figure 5A). Stocks of CSLI have been constantly increasing in this phase, also growing more than tenfold from 2010 to 2020. A large part of this inflow landed in strategically important sectors such as energy generation, automotive and other transport industries like air and space travel, or in high-tech industries like mechanical engineering, environmental and bio-technologies, or telecommunications. Together, these strategic sectors made up almost $70 \%$ of all CSLI into Germany between 2014 and $2017^{100}$ and represent also a majority across the whole decade (Figure 5B).

\footnotetext{
99 Interviewee 06.

100 Jungbluth, Kauft China systematisch Schlüsseltechnologien auf?, p. 36.
} 
FDI from China to Germany, 2010-2020

Source: AEI China Investment Tracker

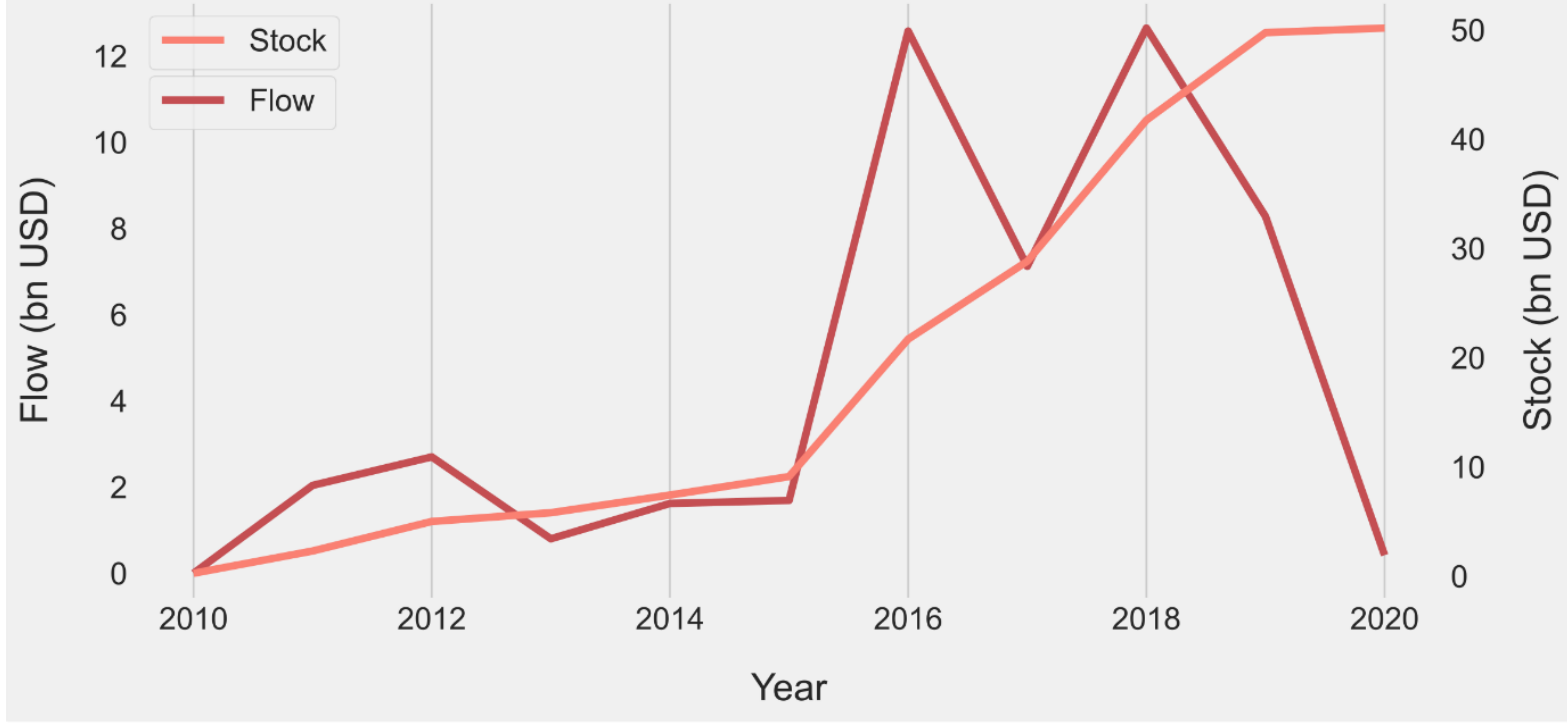

(B)

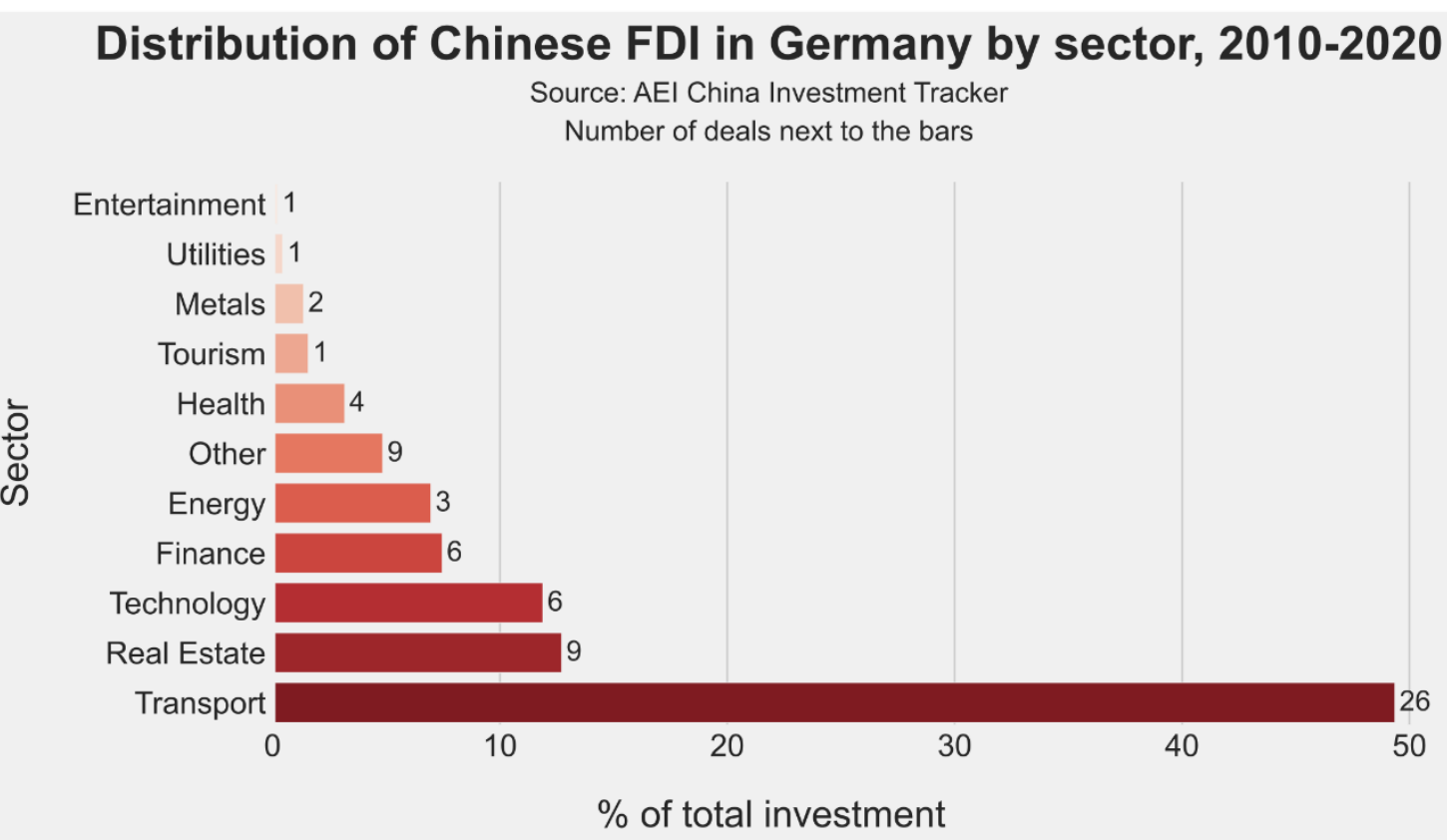

Figure 5: (A) Flows and stocks of Chinese FDI in Germany from 2010 to 2020 (in bn USD). (B) Distribution of Chinese FDI by sectors (in percent).

At the time, crisis-induced low asset prices posed a welcome opportunity for state-led investors to "grab" important smaller and larger German industrial firms comparatively cheaply. Consequently, the parliament decided to amend an existing foreign trade law (Außenwirtschaftsgesetz) in 2009, thereby lowering the threshold for foreign acquisitions to 
25 percent of a firm's voting rights, and extending the law's review mechanisms to all economic sectors. As a precautionary measure, the amendment attracted both praise for protecting key sectors and highly competitive SMEs from unwelcome takeovers, as well criticism for possibly jeopardizing the export-oriented and internationally interdependent German economy. ${ }^{101}$ The move reflects the different starting positions of the British and the German investment regimes around 2008-2010. German discussions were already centered on issues of economic sovereignty and national competitiveness before the discussions about CSLI took off later in the decade. Likewise, the dilemma of Germany as both, home to industrial know-how and assets and an open, export-dependent economy already delivered the foil for the later discussions about CSLI and weighting investment openness versus national security.

From 2010 onwards, the presence of CSLI started to grow in Germany. In 2012 alone, Chinese companies invested in automotive supplier Kiekert, concrete pump manufacturer Putzmeister, and forklift maker Kion. The Chinese buying spree increased in speed and size in subsequent years. A think tank report from 2013 describes an increasing unease in Germany: while these investments are beneficial for the German economy as a whole, they are also met by real reservations regarding the political implications of such deals. ${ }^{102}$ We can detect an incremental change towards more attention for CSLI among policy-makers, while they are not yet fully embracing clear protectionist positions. The amended foreign trade law, as a middle way between being protective but still open for investment, represents the political compromise reached after 2010. This weak compromise would be tested in 2014 and 2015, when the political discussions about the role of Chinese investment in strategic sectors started to play a significant role again. ${ }^{103}$

\section{From 2016 onwards: rude awakenings and new protectionism}

This relative calm of the discussion about CSLI came to an official end in January 2016, when the state-owned giant ChemChina announced the takeover of German machinery manufacturer KraussMaffei. The takeover was the first of a record series of Chinese takeovers

\footnotetext{
101 Sandra Heep, "Staatsfonds ante portas: Deutsche Reaktionen auf den wachsenden Einfluss staatlicher Investitionsgesellschaften," China Analysis No. 65 (2008).

102 Cora Jungbluth, "Aufbruch Nach Westen - Chinesische Direktinvestitionen in Deutschland," Bertelsmann Stiftung (2013), https://www.bertelsmann-stiftung.de/fileadmin/files/user_upload/Aufbruch_nach_Westen.pdf. 103 Interviewee 05.
} 
in Germany during 2016, with high-profile cases such as those of robotics firm KUKA or waste incineration firm EEW. While not all of the deals were led by state-owned firms, the perceived closeness of economic and political power in China shaped the debate about the "sellout to China" in Germany. The KUKA-case was widely perceived as a wake-up call that turned the tide on the discussion of strategic CSLI in Germany. ${ }^{104}$ The explosive increase of Chinese investment in Germany between 2015 and 2016 was dubbed a Chinese "Germany-craze" by the financial press. ${ }^{105}$ Politicians from different sides of the political spectrum called for a level playing field and even stricter applications of existing investment screening laws. ${ }^{106}$ The different nature of the pre-2016 and the post-2016 discussion speaks to our theoretical assumptions on incremental ideational change: the opposition and rejection of CSLI increases with its absolute presence in strategic sectors in Germany. Pre-2016 this concerned singular cases and low overall stocks (Figure 5A). However, the steep rise of CSLI into strategic sectors around 2015/16 increased the legitimacy and relevance of protectionist arguments almost proportionally. It is however not the case that pre-2016 the discourse was non-existent or only triggered by the 2015/16 inflows, as we documented here.

This increasingly protectionist mood also spilled over into political action. Opposition parties criticized the missing usage of investment protection instruments, and called for greater scrutiny when German high-tech firms become takeover targets of state-supported firms. ${ }^{107}$ On the government side, newspaper reports suggested that political resistance from the economics ministry and trade union representatives led to the failure of a planned takeover of electricity firm and semiconductor producer Osram through CSLI at the end of 2016. ${ }^{108}$ On top of this growing resistance, US president Obama issued an executive order to block the takeover of German chipmaker Aixtron, which was backed by the strategic state-owned Sino

\footnotetext{
104 Interviewee 05; 07; 08.

105 Manager Magazin, "China im Deutschland-Wahn," Manager Magazin, 27 December, 2016, https://www.manager-magazin.de/unternehmen/industrie/uebernahme-rekord-2016-china-im-deutschlandwahn-a-1127581.html.

106 Manager Magazin, "China im Deutschland-Wahn."

107 Die Grünen, “Ausländische Direktinvestitionen," Parliamentary Group Die Grünen (Green Party), 22 March, 2017, https://www.gruene-bundestag.de/themen/wirtschaft/auslaendische-direktinvestitionen.

108 Thomas Fromm, "Chinesen geben überraschend Osram-Übernahme auf," Süddeutsche Zeitung, 13 December, 2016, https://www.sueddeutsche.de/wirtschaft/osram-chinesen-geben-ueberraschenduebernahme-von-osram-auf-1.3293889.
} 
IC fund. ${ }^{109}$ These rather strong reactions from 2016 onwards are almost proportional to the increase of CSLI in strategic sectors. Following our theoretical assumptions, we explain this with the visibly changing political calculus re-appreciating security considerations at the expense of investment attraction. More precisely, this calculus within the policy-making community converged on two issues: skepticism towards Chinese state-backed takeover attempts and the protection of sensitive high-tech industries where German firms are worldleading. ${ }^{110}$ The idea of attracting forms of CSLI that were beneficial for the domestic economy was increasingly discontinued. The German policy-making community now shifted to a cleareyed geoeconomic competition with the Chinese state and its state-backed investment vehicles. ${ }^{111}$ This argument is also backed by the following developments in 2017, when this position became further consolidated in the policy-making community through a renewed tightening of the foreign trade law. The new amendment introduced, among others, extended reporting requirements for investments related to public safety and order. It also extended the list of security-relevant key technologies, reflecting the ideational change that was driven by the rise of CSLI in sensitive sectors. ${ }^{112}$

Shortly after this ideational shift that manifested in legal change, the next major case of CSLI tested and expanded the new investment regime's boundaries. In 2018, the stateowned State Grid Corporation of China (SGCC) attempted the acquisition of a 20 percent stake of electricity provider $50 \mathrm{Hertz}$. For the first time, the German government openly intervened twice into this looming acquisition. First, it urged the majority owner of 50Hertz (Belgian Elia) in the spring to acquire outstanding shares that were supposed to be bought by SGCC. It then went even further and acquired itself the remaining 20 per cent stake that SGCC aimed to buy in the summer of $2018 .{ }^{113}$ This development is a case in point for the emerging hard stance

\footnotetext{
${ }^{109}$ See Monica Houston-Waesch, "China Investment Fund Makes Offer for German Chipmaker Aixtron," Wall Street Journal, 23 May, 2016, https://www.wsj.com/articles/china-investment-fund-makes-offer-for-germanchipmaker-aixtron-1463991825. The Obama administration followed a recommendation by CFIUS, which this institution could give because a branch of Aixtron is located in California and is hence an actor within the US technology market.

110 Interviewee 07.

111 Interviewee 05; 06; 07.

112 Chamber of Commerce Hamburg, "Änderung der Außenwirtschaftsverordnung bei Auslandsinvestitionen," Handelskammer Hamburg, (2017), https://www.hk24.de/produktmarken/beratung-

service/international/laenderinformationen/europa/deutschland-aenderung-awv-2017-3790242.

113 German Government, "Antwort der Bundesregierung auf die kleine Anfrage Abgeordneter der Fraktion der FDP. Drucksache 19/3796," Bundestag, 10 September, 2018, https://dip21.bundestag.de/dip21/btd/19/041/1904195.pdf.
} 
German policy-makers took towards CSLI. The government directly instructed the state-owned development bank KfW to buy the stake in 50Hertz. This circumvented the 2009 foreign trade law amendment, which only targeted acquisitions beyond 25 percent of a firm's shares. Citing security and critical infrastructure interests, the government mobilized extraordinary state powers to aggressively block CSLI in critical infrastructures. This move was so unprecedented that it sparked public outrage, being described as a "dirty state trick". ${ }^{114}$ The blockade of the takeover of machine builder Leifeld by Chinese investors in August 2018 on the grounds of national security interest followed this pattern.

These developments signaled a clear incremental escalation of German policy-making vis-à-vis CSLI in sensitive and strategically important sectors. In accordance with our argument on incremental ideational change, this led to yet another amendment of the foreign trade law towards the end of 2018, this time importantly lowering the threshold for critical investments from 25 percent to 10 percent. This reflected threshold problems in the case of $50 \mathrm{Hertz}$, and demonstrated the willingness of the political elite to ramp up existing state powers to meet the perceived challenge from CSLI in particular. The direct relation between the $50 \mathrm{Hertz}$ (and other smaller cases) and the conducted legal changes have been deemed highly likely by observers and parliamentary inquiries afterwards. ${ }^{115}$ At the same time, the German government began, together with Italy and France, to coordinate European efforts aimed at stricter EU investment screening mechanisms on the basis of these ideational and legal changes. ${ }^{116}$ In 2019, the first EU-wide coordination mechanism for investment screening was adopted. ${ }^{117}$ Since then, a majority of EU countries has started to implement measures in line with this new regulation, among which is also Germany, which tightened its foreign trade law

\footnotetext{
${ }^{114}$ Andreas Mihm, "Ein Mieser Staatstrick," Frankfurter Allgemeine Zeitung, 3 August, 2018, https://www.faz.net/aktuell/wirtschaft/unternehmen/bundesregierung-mischt-sich-in-50-hertz-kauf-ein15720312.html.

115 Thomas Kohlmann, "Höhere Hürden Für Sensible Firmenübernahmen in Deutschland," Deutsche Welle, 18 December, 2018, https://www.dw.com/de/h\%C3\%B6here-h\%C3\%BCrden-f\%C3\%BCr-sensiblefirmen\%C3\%BCbernahmen-in-deutschland/a-46778279; German Government, "Antwort der Bundesregierung auf die kleine Anfrage Abgeordneter der Fraktion Die Linke. Drucksache 19/18466," Bundestag, 5 May, 2020, https://dserver.bundestag.de/btd/19/189/1918929.pdf.

${ }^{116}$ German Government, "Antwort der Bundesregierung auf die kleine Anfrage Abgeordneter der Fraktion FDP."

117 European Commission, "Press Release: EU Foreign Investment Screening Mechanism Becomes Fully Operational," European Commission, 9 October, 2020, https://ec.europa.eu/commission/presscorner/api/files/document/print/en/ip_20_1867/IP_20_1867_EN.pdf.
} 
yet another time. Despite attention-grabbing cases like the KUKA takeover, the described ideational change up to this point was clearly incremental and driven by CSLI:

\footnotetext{
"I think it is probably incremental. With a lot of major steps - and I think KUKA is a major step - but KUKA alone is not explaining it. It is the whole thing, it is loans, Belt and Road, you have this kind of procurement debate going on; there is currently I think again in Hamburg, there is CCCC [a Chinese state-owned construction company] plans to build something there. It is all these little steps that feed into the debate [among policy-makers]. And I don't think it is one turning point."118
}

By the end of a decade of (faster and slower at times) incremental ideational change, the dominating discourse in the German policy-making community converged on the necessity to protect national security and technological autonomy in the broadest sense. This vision was articulated in the "Industrial Strategy 2030" paper from December 2019. ${ }^{119}$ Herein, the government describes "maintaining technological autonomy"120 as one of three pillars of a new industrial strategy, especially against "state-controlled or subsidised companies from third countries". ${ }^{121}$ This means curbing technology transfers and tightening investment screening mechanisms in line with the strategy used so far. At the same time, the new elements include employing domestic firms to act as "white knights" in order to acquire stakes under threat from a foreign takeover. Moreover, there is an explicit reference to using the state-owned development bank KfW to step in as shareholder of "last resort", 122 reflecting the discussed 50Hertz-case and now designated as official government policy. The industrial strategy paper hence summarizes a decade of ideational change among policy-makers, which have converged on the idea that a new dirigisme, involving investment screening and state intervention, is appropriate to counter threats to German national security and technological autonomy driven by CSLI.

\footnotetext{
118 Interviewee 05.

119 BMWi, "Industrial Strategy 2030. Guidelines for a German and European Industrial Policy," Federal German Ministry for Economic Affairs and Energy, (2019), https://www.bmwi.de/Redaktion/EN/Publikationen/Industry/industrial-strategy-

2030.pdf?_blob=publicationFile\&v=7.

120 BMWi, "Industrial Strategy 2030," p. 27.

121 BMWi, “Industrial Strategy 2030," p. 31.

122 BMWi, "Industrial Strategy 2030," p. 28.
} 


\section{Discussion: The China-effect in comparative perspective}

The findings of our study reveal a set of common characteristics that shaped the process of ideational change in uneven, but similar ways for the UK and Germany. We contend that despite different start and endpoints, we saw in both cases a movement towards stricter protectionism caused by the rise of CSLI in sensitive sectors (Figure 6). This means that increased volumes of CSLI, as the independent variable, affected the changes documented in the previous section:

\footnotetext{
"To the extent that we are seeing a rise of hostility or skepticism about foreign investment - particularly state-led investment - in Europe, it has to do with first with the rise of nationalism [...] and secondly the perception that a lot of this is coming from a particular state: China"123
}

In line with quality standards for methods such as process tracing ${ }^{124}$, we scrutinize these findings against possible objections for each of them.

(1)

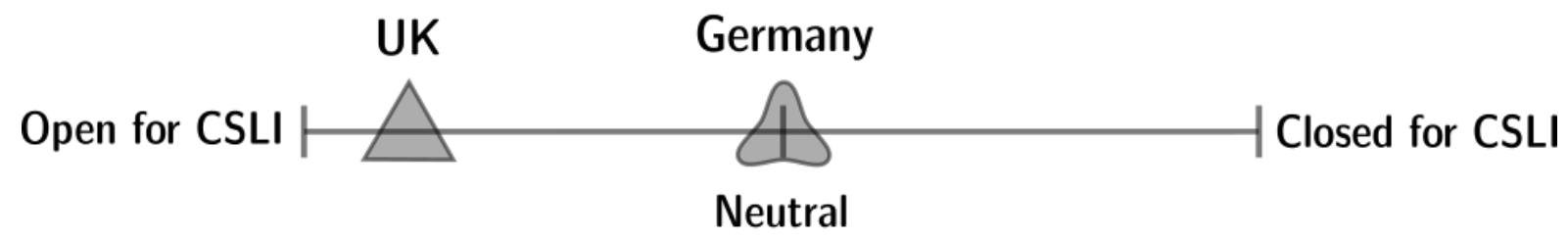

(2)

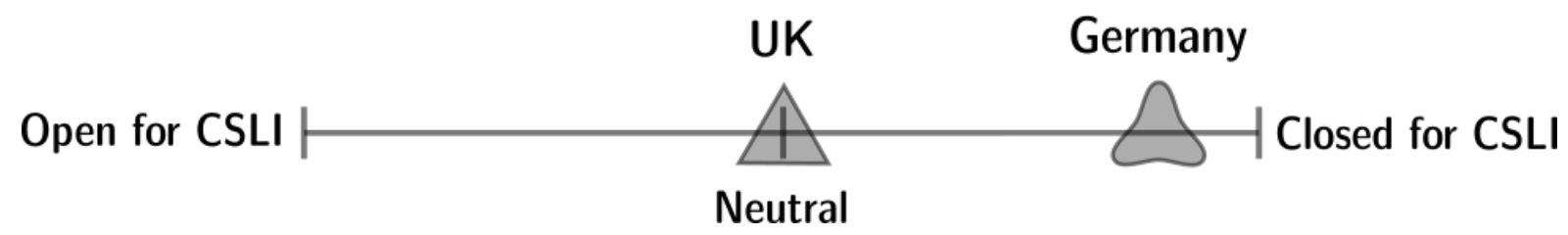

Figure 6: Actual change of openness of investment regimes for CSLI over time. (1) Depicts the situation after the GFC, (2) at the end of the decade (2020).

\section{Timing and omitted variable bias}

A first possible objection to the findings could be that both cases introduce stricter regimes not because of the rise of CSLI, but for other reasons. Hence, we could have omitted the real

\footnotetext{
123 Interviewee 03.

${ }^{124}$ Checkel, "Process Tracing and International Political Economy."
} 
independent variable in our analysis. This could for example be a general "rise of nationalism" as mentioned by one of the interviewees above.

However, a key common characteristic that gives argumentative leverage to the Chinaeffect is the timing of both cases. Initial differences after the GFC in treating CSLI give way to a strong convergence from 2016 onwards. In the UK, early attempts to attract CSLI after the crisis were more pronounced than in Germany, where a general skepticism towards state-led investment, including Chinese, prevailed. These differences can partly be explained by the different growth models of both cases: the financialized, FDI-dependent UK model faces different incentives to attract investment than the export-oriented German model that can be more selective towards FDI inflows, especially into its competitive key industries like automobiles, machine engineering, and world-leading niche SMEs. ${ }^{125}$ However, these initial differences flatten out with time. The adoption of investment screening and national security laws in the period from 2018 onwards shows how policy-makers in both countries react in almost identical ways to the rise of CSLI and the following takeovers. In our view, this speaks strongly for the causal mechanism we identified as the China-effect. Possibly omitted other variables such as a general rise of nationalism are confounding variables that characterize the general direction of "Western" politics in the last years, but not the concrete introduction of specific protectionist measures. Table 1 summarizes this temporal comparison of the Chinaeffect for both cases.

125 Interviewee 03. 


\begin{tabular}{|c|c|c|c|c|}
\hline & 2007-2009 & $2010-2013$ & $2015 / 16-2018$ & 2018 onwards \\
\hline \multirow[t]{2}{*}{ UK } & $\begin{array}{l}\text { Caution towards some } \\
\text { forms of state-led } \\
\text { investment (Labour } \\
\text { government). }{ }^{126}\end{array}$ & $\begin{array}{c}\text { FDI attraction } \\
\text { offensive, new "golden } \\
\text { era" with Chinese } \\
\text { investments (Cameron } \\
\text { government). }\end{array}$ & $\begin{array}{l}\text { Growing skepticism } \\
\text { towards China; first } \\
\text { cases of CSLI blocking } \\
\text { (May government). }\end{array}$ & $\begin{array}{l}\text { Introduction of strict } \\
\text { measures based on } \\
\text { national security } \\
\text { grounds (national } \\
\text { security and } \\
\text { telecommunications } \\
\text { bill). }\end{array}$ \\
\hline & neutral & neutral to positive & $\begin{array}{c}\text { neutral to } \\
\text { negative }\end{array}$ & negative \\
\hline \multirow[t]{2}{*}{ Germany } & $\begin{array}{l}\text { Debates about political } \\
\text { nature of state-led } \\
\text { investment; } \\
\text { amendment of foreign } \\
\text { trade law. }\end{array}$ & $\begin{array}{l}\text { Calming of debate; } \\
\text { partial attraction of } \\
\text { SWF-investment. } \\
\text { Growing presence of } \\
\text { CSLI in Germany, but } \\
\text { reciprocal interest } \\
\text { prevails. }\end{array}$ & $\begin{array}{l}\text { First problematic } \\
\text { takeovers; } \\
\text { amendment of } \\
\text { foreign trade law }\end{array}$ & $\begin{array}{c}\text { Pushing for EU } \\
\text { investment screening; } \\
\text { usage of KfW to block } \\
\text { transactions; Industrial } \\
\text { Strategy } 2030 .\end{array}$ \\
\hline & negative & neutral & negative & strongly negative \\
\hline
\end{tabular}

Table 1: Attitudes towards CSLI in both cases over time.

\section{Working mechanism: where does national security begin and end?}

A second possible objection could be leveraged against the key working mechanism we describe for our intervening variable. We argued that the China-effect consists of the rise of CSLI that transforms the preferences of policy-makers: it depreciates the relevance of FDIattraction and appreciates the relevance of national security, which might be infringed by certain types of investment (like CSLI) in sensitive industries. One major objection could be that

\footnotetext{
${ }^{126}$ Sumeet Desai, "Sovereign Funds Need to Follow Rules -UK's Darling," Reuters, 19 October, 2007, https://www.reuters.com/article/group-britain-funds/update-1-sovereign-funds-need-to-follow-rules-uksdarling-idUSN1944574820071019?edition-redirect=uk.
} 
the changes we see are rather induced by the transformation of China into a (geo-)economic and systemic competitor for "Western" states. It would then not be national security, but rather the re-appreciation of factors of national competitiveness and geopolitical competition that drives the working mechanism we describe.

We indeed find such indications in our data. For instance, some of our interviewees emphasize the systemic competition with China, especially in the German case. ${ }^{127}$ Economic and geopolitical competitive dynamics seem to be driving at least part of the rising skepticism towards CSLI. At the same time, we need to be careful to distinguish between such "third order" changes of a paradigmatic nature from policy-shifts as discussed in this paper, which are rather "second order" changes of policy instruments and settings. ${ }^{128}$ The view of China as a systemic competitor is a more fundamental and abstract paradigm change in European politics which is still underway. ${ }^{129}$ To frame such large-scale paradigm transformations as driving concrete policy-changes would be imprecise. Rather, the rise of CSLI in key industries can be regarded as a concrete factor contributing to the general notion of China as a systemic competitor. At the same time, CSLI has been the clear driver of concrete policy-changes such as the introduction of investment screening mechanisms. ${ }^{130}$

We also collected and demonstrated concrete evidence on how national security considerations are being re-appreciated through the rise of CSLI. In both cases, however, the understanding of what national security is, and how it could be infringed by CSLI differs markedly. In the German case, initial abstract fears about state capital possibly infringing national security ${ }^{131}$ transformed into a clear set of political objectives by the end of the decade. The latest Industrial Strategy 2030 paper by the economics ministry in Germany clearly sets out a broad understanding of national security that backs technological autonomy and also urges the EU to rethink the criteria for investment screening in the tension between public order and national security. ${ }^{132}$ German policy-makers display a broad understanding of national security, which also crucially involves the protection of its industrial base and knowledge edge in global technological competition vis-à-vis China ${ }^{133}$ :

\footnotetext{
127 Interviewee 06; 10.

128 Hall, "Policy Paradigms, Social Learning, and the State," p. 279.

${ }^{129}$ Lavery and Schmid, "European Integration and the New Global Disorder."

130 Interviewee 03; 05; 09.

131 Heep, "Staatsfonds ante portas."

132 BMWi, "Industrial Strategy 2030."

133 Interviewee 06; 07.
} 
"I think there is a shift to economic security rather than a very narrow definition of infrastructure and defense. Obviously, they are still crucial. But I think there is - and that is slowly coming in - 'okay we need to focus also on what this means economically in 10, 20 years'" ${ }^{\prime 34}$

In the UK, issues of national security mostly became politically relevant in concrete cases of infrastructure or energy security matters. Cases like the Hinkley Point C controversy provided concrete grounds on which the May government decided to act and bring the issue of national security into the discussions about CSLI. These case-based debates of national security issues - which also come back in the 5G-case some years later - reflect the fact that UK policymakers still display a rather ambivalent relation to the topic. ${ }^{135}$ As has been argued in a parliamentary debate on the National Security and Investment Bill, the policy-making community seems to adopt a rather flexible and less well-defined idea of national security when it comes to foreign investment. ${ }^{136}$

Coming from different political economies, policy-makers in both countries judge the security risks arising out of CSLI to some degree differently. What has become clear, however, is that a re-appreciation of (different understanding of) national security drives legal changes in both cases.

\section{Challenging causality}

A third objection that follows from the scrutiny of the two previous points pertains to the question of causality. As we argue in this paper, we see the rise of CSLI in sensitive or strategic sectors as driving the preference changes of policy-makers that then lead in the last instance to changes of their respective investment regimes. The potential objection here would be that our case studies do not strictly establish ideational causation, but rather describe ideational changes in the preferences of policymakers. Consequently, the described changes could also be caused by different factors than the independent variable, and the dependent variable could be driven by other factors than the changing preferences of policymakers.

Although we acknowledge that these are possible scenarios, we do not deem them very likely compared to alternative explanations. The first point about what really drives the preference change of policymakers has already been addressed in the first two subsections of

\footnotetext{
134 Interviewee 05.

135 Interviewee 03.

136 UK Parliament, "National Security and Investment Bill."
} 
this section (see above). We think that neither an omitted variable nor a fundamentally different working mechanism causes the preferences of policymakers to change over time. The second question of whether preference change drives legal (or material) change is slightly different as we leave the exact mechanism here somewhat open. For the sake of our argument, we assumed that the existence of legislative changes needs to be preceded by preference changes on the side of policymakers - all other factors being equal. This second part of our explanation certainly requires more in-depth exploration in future research as we also note in the conclusion. For the purposes of establishing the China-effect, however, it is not relevant how exactly preference change translates into actual change. The alternative, namely that policymakers have not undergone a change in their preferences before they enacted legal changes, is highly unlikely. The only alternative explanation would be that policymakers have been forced into these changes, or have done so unknowingly - both of which can be ruled out.

It is thus especially the effect of the independent on the mediating variable that is decisive for the question of causality, which we aimed to scrutinize in the preceding comparison. The strong descriptive component of the case studies stems from the need to provide arguments for the incremental change in actor preferences we theorized (and to rule out arguments of sudden change). However, within the case studies, we also provided discussions of our argument at critical inflection points of policy change, such as the challenge of the Hinkley Point $\mathrm{C}$ investment in the UK or the adaptation of the foreign trade law in Germany following the use of extraordinary state powers. As such, we bolstered our claim that the rise of CSLI in sensitive sectors drives these incremental changes with the empirical material employed in the case studies.

At the same time, as we argued in the section "The China-effect", we understand our mechanism not as one of pure ideational causation. Rather, we seek to map out the interplay of material factors (the rise of CSLI) and its ideational consequences that in turn influence the forms and possibility of FDI inflows in general. Instead of trying to establish causality by ruling out any non-ideational factors, we conduct a "thick description" of the described processes that make some explanations more likely than others. Through this, we establish a form of most plausible explanation for the dynamics we describe in-depth in our case studies. In sum, we think that both ends of the relationship we describe are the most robust explanations for 
the China-effect, while we stay open for additional evidence in future research that would challenge or alter our arguments.

\section{Why incremental change? Explaining ideational transformations in the wake of China's rise}

A fourth objection could be leveraged against our theoretical framework for studying policychange. Many of our interviewees mention key events that were driving change in both cases, such as the KUKA-case in Germany ${ }^{137}$ or the Hinkley Point C controversy in the UK. ${ }^{138}$ This could be interpreted as a transformation through key historical inflection points as is often emphasized in the literature on institutional change. Such an interpretation would stand against our claim that incremental ideational change led to the described transformations of the respective investment regimes.

We acknowledge the significance of key events for ideational change, also in our comparison: both cases entail such "turning points" in policy-making. At the same time, we hold that these events are not sudden ideational paradigm changes, but rather moments of a gradual transformation of existing ideas. A main aspect of incremental ideational change is that ideas do not entirely replace each other, but that "new" ideas about a specific issue (like CSLI) grow out of a plethora of existing ideas and their relations to each other. ${ }^{139}$ We documented these changes of the elements of an idea or ideational constellation also in our study. ${ }^{140}$

The ideational changes that preceded the introduction of investment screening mechanisms in both our cases build on elements of existing ideas and institutional ensembles. In the UK case, the Cameron government perceived the UK broadly as an open, globalized economy keen on attracting FDI for domestic growth. In the German case, the perception of Germany as a generally open economy was broadly accepted and derived from its status as a global export champion in need of open and fair global markets. Policy-makers in both countries were, at least in the early post-crisis phase, also to a certain degree influenced by the status of the EU as an open economic area seeking to create a liberalized global level playing

\footnotetext{
137 Interviewee 07; 10.

138 Interviewee 09.

${ }^{139}$ Carstensen, "Ideas Are Not as Stable as Political Scientists Want Them to Be," p. 601.

140 This documentation also clearly shows the sequence and directionality of events: it is the volume of CSLI in strategic sectors that drives policy change rather than the other way around. Both cases showed investment regime changes almost in proportion with the increase of CSLI in domestic strategic sectors after the increase took place. The reconstruction of this process through the lens of incremental ideational change hence also helps in ruling out alternative hypotheses regarding the directionality of the postulated causal mechanism.
} 
field for trade and investment. Furthermore, both had an institutionalized, but relatively weak mechanism for screening and possibly blocking foreign investment, especially in the UK case.

From this starting point, incremental ideational change led to the outcomes we have discussed above. In the UK, policy-makers tried to square the openness of their economy - and the post-Brexit need for incoming investment - with the broadly shared perception that specific types of investment (namely CSLI) were to be prevented in specific areas important for national security (namely energy and critical infrastructure). Incremental ideational change first led to a changed stance towards the involvement of CSLI in nuclear infrastructure in 2015/16; then, to a critical assessment of the Huawei-involvement in $5 \mathrm{G}$ in 2017/18; and, finally, to a fundamental reform of the UK investment regime mainly through the two Bills introduced to parliament in 2020. At the end of this incremental change, UK policy-makers moved visibly towards a critical stance on CSLI, without adopting a full-blown hostility to FDI as such. We regard this as a clear incremental and partial adjustment of existing ideas about foreign investment and its role in the UK economy.

In the German case, the existing idea of a globally integrated German export machine in favor of a level playing field was transformed by re-appreciating the role of its industrial base in enabling the German export-oriented growth model itself. Different from the UK case, we did not see primarily the framing of critical infrastructure as in need of protection, but rather the rediscovery of the vulnerability of Germany's industrial and technological assets to foreign state-led capture as the main driver of ideational change. Starting with increasing volumes of CSLI in 2014/5; followed by the record investment year of 2016, including massive state-led takeovers, and the direct state confrontations with CSLI in multiple cases in 2018, German policy-makers developed stricter and clearly negative attitudes towards CSLI. What seemed in the early days as a matter of balancing the strategic interests of the German export economy with a rapidly growing China, became in 2020 a clear protectionist stance towards CSLI. ${ }^{141}$ We argue that through the disillusionment with China as global competitor, and with the changing perception of CSLI in particular, German policy-makers underwent an even stronger and more visible ideational change over the last years than in the British case. This also becomes clear from the constant re-amendments of its existing foreign trade law towards more and stricter screening practices, which we have established as being driven mainly by CSLI:

\footnotetext{
${ }^{141}$ Interviewee 06.
} 
"[EU-wide investment screening] was definitely triggered by China. The main reason for the discussion is certainly China. Because the other investments, they simply cause fewer discussions, also in terms of numbers. No, of course it doesn't say so explicitly, but all the changes in the law that we've seen here in Germany in recent years - and the initiatives at the EU level [by Germany and others] - can clearly be traced back to Chinese economic activities". ${ }^{142}$

\section{Conclusion: A research agenda for CSLI}

Chinese (state-led) investment became a major force in global capitalism over the last two decades. While the particular domestic and international reasons for this rise are well-studied, its political effects are less so. We proposed a simple working mechanism to understand how CSLI influx in strategic sectors causes policy-makers of major European economies to adopt a stronger orientation towards national security issues at the expense of investment attraction. We have shown how this pressure affects different varieties of capitalism to different degrees, but in similar ways. While different growth models may experience these pressures from different starting positions, clear convergence dynamics become palpable. Our comparative case study demonstrated this China-effect for two dissimilar cases in the comparative capitalisms nomenclature.

Our study marks the starting point for a broader research agenda on CSLI. First, we discussed cases with "hard evidence" in the form of legislative changes. These changes are of course part of a broader trend of rising skepticism towards CSLI, which is hard to measure and is often only subtly expressed in policy-making. In other words, we most likely only captured the legislative peak of the iceberg. This iceberg is the underlying discourse and the changing attitudes that only lead in their last instance to legislative changes. ${ }^{143}$ Future research needs to excavate and closely describe these ideational dynamics over time. This will grant us a better understanding of the ideational processes at work, which we could only indirectly measure in this study.

\footnotetext{
142 Interviewee 07.

143 See, e.g., Rogelja and Tsimonis, "Narrating the China Threat,"; Ka Zeng and Xiaojun Li, "Geopolitics, Nationalism, and Foreign Direct Investment: Perceptions of the China Threat and American Public Attitudes toward Chinese FDI," The Chinese Journal of International Politics Vol. 12, No. 4 (2019), pp. 495-518.
} 
Second, we suggest broadening the scope of the analysis both in terms of capitalist varieties as well as geographically. Our treatment of Germany and the UK covers a specific type of high-income economy with large strategic sectors, where political backlash towards CSLI is well explainable. We do not expect to find such a China-effect in low-and middle-income economies that are often desiring (Chinese) investment; and which have very different incentive structures influencing the weighting of investment attraction and national security. Chan and Meunier ${ }^{144}$ for example find that support for an EU-wide screening mechanism is higher in European countries with Chinese FDI in strategic sectors (such as France, Germany, or Italy), while it is lower for countries with such investment in non-strategic sectors (such as many East-European countries). Recent research has analyzed such effects of CSLI expansion beyond Europe into Latin America ${ }^{145}$, or Africa ${ }^{146}$ for example. We hope that our study inspires more political economy and comparative research that further develops our understanding of the historical and contemporary determinants of Chinese cross-border investment. ${ }^{147}$

Third, our results speak to broader developments in Europe and beyond that signify a "geopoliticization" of trade and investment policies. ${ }^{148}$ Recent research has outlined the global disorder which both feeds this geopoliticization, but also presents the new conditions under which European integration is taking place. ${ }^{149}$ If neoliberal globalization was the condition under which European countries adopted the liberalization of trade and investment policies, the rise of a more statist form of globalization can have the inverse effect of closing Europe to different forms of state-led investment. There will of course be major intra-European divisions about how to treat a rising China, as is already visible today. Our study covers one important part of this complex, namely the European "core" economies; while it does not touch upon the so-called "periphery", which will again have different incentives to be more embracing towards rising Chinese investment.

\footnotetext{
${ }^{144}$ Chan and Meunier, "Behind the Screen."

145 Stephen B. Kaplan, Globalizing Patient Capital: The Political Economy of Chinese Finance in the Americas (Cambridge: Cambridge University Press, 2021).

146 Lee, The Specter of Global China.

147 Pippa Morgan and Yu Zheng, "Tracing the Legacy: China's Historical Aid and Contemporary Investment in Africa," International Studies Quarterly Vol. 63, No. 3, 558-73; Axel Dreher, Andreas Fuchs, Brad Parks, Austin M. Strange and Michael J. Tierney, "Apples and Dragon Fruits: The Determinants of Aid and Other Forms of State Financing from China to Africa," International Studies Quarterly Vol. 62, No. 1, 182-94. 148 Meunier and Nicolaidis, "The Geopoliticization of European Trade and Investment Policy." 149 Lavery and Schmid, "European Integration and the New Global Disorder."
} 
In sum, whether and to what extent the China-effect holds true beyond the two compared cases presented here remains to be tested and challenged in further research. We hope that the working mechanisms we delineated, the theoretical perspective we brought in, and the comparative empirical work we conducted build a strong basis for a broad and inspiring research agenda for the future. 